\title{
An Inventory of the Vascular Flora of Fort Greely, Interior Alaska
}

Charles Racine, Robert Lichvar, and Michael Duffy

February 2001

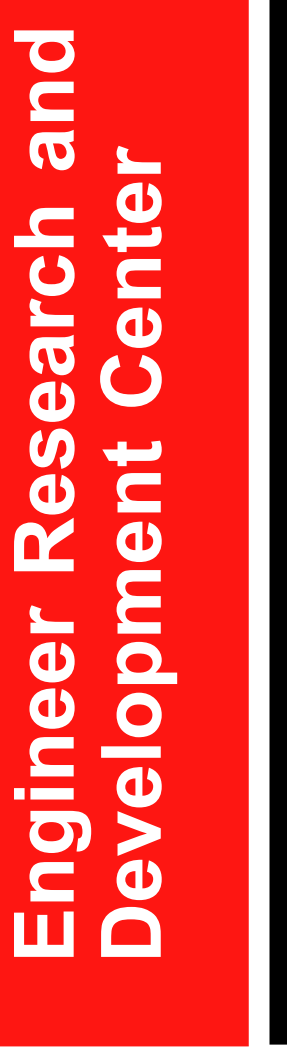


Abstract: This inventory of the vascular flora of Fort Greely in interior Alaska was conducted sporadically during summer 1996, 1997, and 1998. Fort Greely covers 0.66 million acres $(267,763 \mathrm{ha})$ and is composed of five major subdivisions: 1) the large floodplains of Jarvis Creek, the Delta River, Delta Creek, and Little Delta River, 2) the surrounding lowlands associated with these rivers, 3) several glacial moraines, 4) two highland areas (Molybdemum Ridge and Dinosaur Ridge), and 5) the higher mountains of the Alaska Range (up to 2000 $\mathrm{m}$ in elevation) along the southern edge of the base. Habitats range from very dry south-facing slopes to for- est, floodplains, wetlands, and alpine tundra. About 100 sites were visited and 723 collections made, which represented 497 taxa of vascular plants from 64 families and 198 genera. A species list for the Fort Greely survey was compiled and is presented here. It is estimated that the vascular plant inventory is relatively complete. The inventory includes 21 rare species being tracked by the Alaska Natural Heritage Program and 11 species representing significant range extensions (>150 km). The relationship of the Fort Greely flora to that inventoried on Fort Wainwright is discussed.

How to get copies of ERDC technical publications:

Department of Defense personnel and contractors may order reports through the Defense Technical Information Center:

DTIC-BR SUITE 0944

8725 JOHN J KINGMAN RD

FT BELVOIR VA 22060-6218

Telephone (800) 225-3842

E-mail help@dtic.mil msorders@dtic.mil

WWW http://www.dtic.mil/

All others may order reports through the National Technical Information Service:

NTIS

5285 PORT ROYAL RD

SPRINGFIELD VA 22161

Telephone (703) 487-4650

(703) 487-4639 (TDD for the hearing-impaired)

E-mail_orders@ntis.fedworld.gov

WWW http://www.ntis.gov/index.html

For information on all aspects of the Engineer Research and Development Center, visit our World

Wide Web site:

http://www.erdc.usace.army.mil 


\section{Technical Report ERDC/CRREL TR-01-5}

\section{An Inventory of the Vascular Flora of Fort Greely, Interior Alaska}

Charles Racine, Robert Lichvar, and Michael Duffy

February 2001 


\section{PREFACE}

The report was prepared by Dr. Charles Racine, Ecologist, Geological Sciences Division, Robert Lichvar, Ecologist, Remote Sensing/GIS Center, and Michael Duffy, contract employee, U.S. Army Engineer Research and Development Center, Cold Regions Research and Engineering Laboratory, Hanover, New Hampshire.

Little or no direct funding for this floristic project was provided and it was accomplished as part of an Ecological Land Survey project (Racine) and Wetland Delineation (Lichvar) for Fort Greely. Funding for these latter studies was provided by the U.S. Army ITAM (Integrated Training Area Management) program through U.S. Army Alaska, Fort Richardson, Department of Public Works, Natural Resources Division, where William Gossweiler and Gary Larsen supported this work.

Martha Raynolds also contributed to this report; technical review was provided by Peggy B. Robinson and Beth Astley.

Several groups on Fort Greely gave assistance by providing their time and experience to familiarize the authors with the natural features of the base, and helped in providing logistical support, such as laboratory space, transportation, and lodging. The Land Condition Trend Analysis group at Fort Greely, headed by Ellen Clark, was particularly helpful. The flight control crews at Allen Airfield (LTC Michaud, CW2 Gorczok, CW3 Isbill, and SSG Jackson) worked under extreme weather and scheduling conditions to provide helicopter support for the Molybdenum Ridge and other surveys west of the Delta River. Torre Jorgenson, Joanna Roth, Barbara O'Donnell, and other ABR, Inc., staff provided much insight and many contributions to the inventory. Barbara O'Donnell assisted in the Molybdenum Ridge inventories. Dale Yokum (U.S. Army Engineer Research and Development Center, Environmental Laboratory, Vicksburg, Mississippi) also assisted with field plant collections. Botanists at the University of Alaska Fairbanks Museum-Herbarium (Carolyn Parker, Alan Batten, Dr. David Murray, and Dr. Elena Conti) provided consultation and support, as well as Emily Bell and other staff at the Gray Herbaria, Cambridge, Massachusetts.

The contents of this report are not to be used for advertising or promotional purposes. Citation of brand names does not constitute an official endorsement or approval of the use of such commercial products. 


\section{CONTENTS}

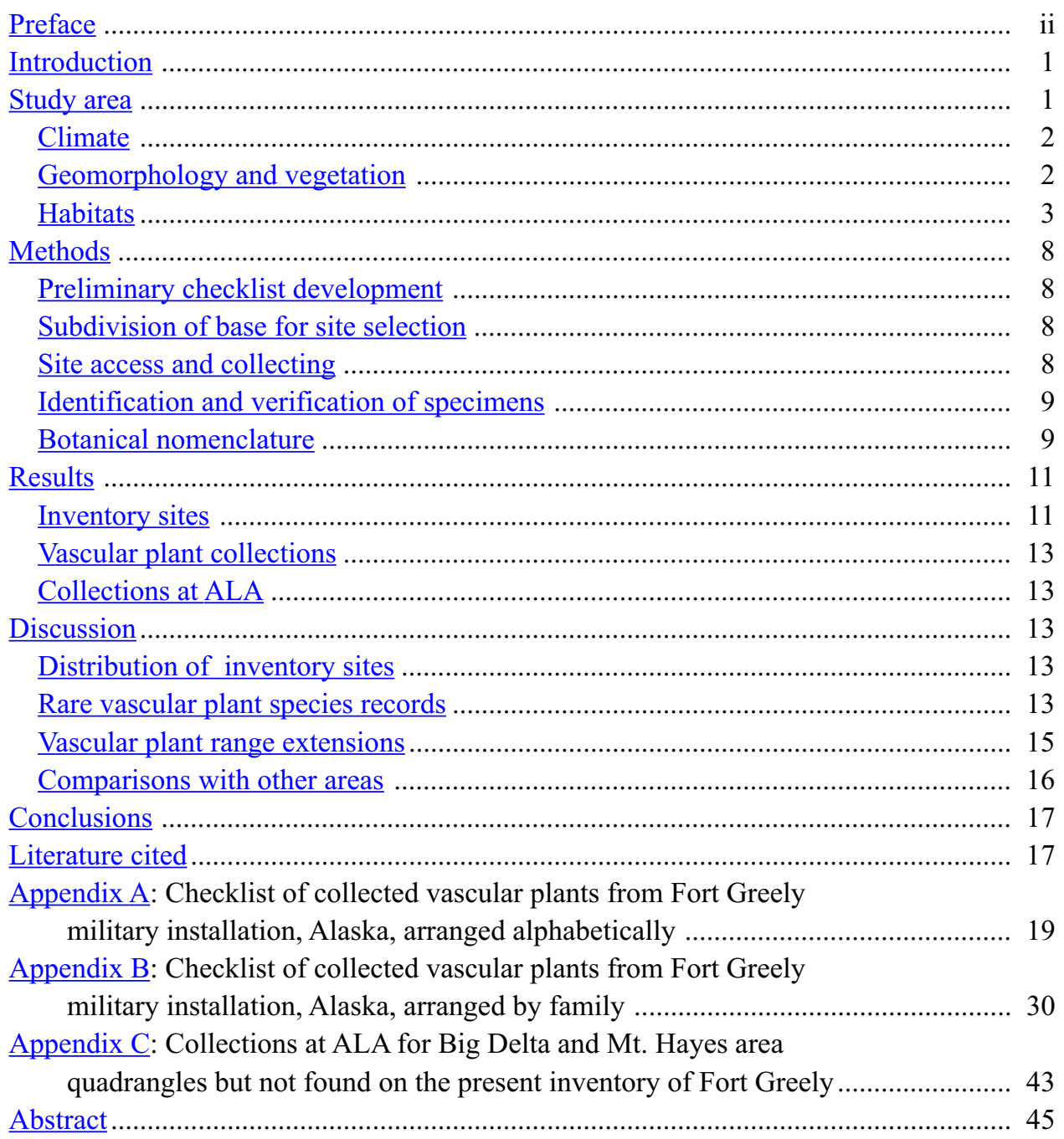

\section{ILLUSTRATIONS}

Figure

1. Fort Greely and Fort Wainwright military installations .................................. 2

2. Topographic features of Fort Greely roads, cantonement, and impact areas ..... 3

3. Major subdivisions of Fort Greely based on physiography from Jorgenson et al. (2001).

4. Major habitats and divisions of Fort Greely ……........................................... 5 
5. Sites where ABR, Inc., conducted an ecological land survey in 1996 and 1998 on Fort Greely

6. Locations of floristic inventory sites where ABR, Inc., M. Duffy, and R. Lichvar collected vascular plants or inventoried vascular plant species, or both

\section{TABLES}

Table

1. Floristic inventory observation and collection sites located on Figure 6 maps ... 12

2. Species on Alaska Natural Heritage Program Biological Conservation Database found on Fort Greely with ranking 


\title{
An Inventory of the Vascular Flora of Fort Greely, Interior Alaska
}

\author{
CHARLES RACINE, ROBERT LICHVAR, AND MICHAEL DUFFY
}

\section{INTRODUCTION}

Beginning in 1994, we (C. Racine and R. Lichvar) initiated floristic inventories of the three U.S. Army bases in Alaska (Forts Richardson, Wainwright, and Greely). These studies were designed to support various Army natural resource programs, including ITAM (Integrated Training Area Management) and LCTA (Land Condition Trend Analysis), as well as to provide information for the Endangered Species Act (ESA), the National Environmental Policy Act (NEPA), and AR 420-74, Natural Resources-Land, Forest and Wildlife Management. The inventory reports for Forts Richardson and Wainwright have been issued as USACE reports (Lichvar et al. 1995, Racine et al. 1997). This is the third and final report in this series. The inventories provide a record of the plant biodiversity in three different northern environments from coastal mountains (Fort Richardson) to interior lowlands, uplands, montane, alpine, and riverine habitats (Forts Wainwright and Greely).

As mentioned, this study provides an inventory and analysis of the existing vascular flora of Fort Greely. Additional objectives include:

- Compile a preliminary list of potential species that might occur on Fort Greely from herbarium and literature sources.

- Subdivide Fort Greely into floristic inventory areas to provide for representative collections from all parts of the facility.

- Collect sets of all voucher vascular plant specimens and provide a set for Fort Greely.

- Identify the specimens collected in the field to the appropriate subspecific level and have final verification of specimens done by specialists at the Univeristy of Alaska Museum and other herbaria.
- Provide species lists for Fort Greely to include relationships to species on Fort Wainwright, floristic regions, habitats, range extensions, and rare species.

\section{STUDY AREA}

Fort Greely is located southeast of Fairbanks near Delta Junction, Alaska, in Interior Alaska (Fig. 1) between the Alaska Range and the Tanana River. The base covers about 231,479 ha (0.66 million acres). Three large rivers and a tributary to one of these, fed by glaciers in the Alaska Range, flow from south to north across the base and empty into the Tanana River (Fig. 2). Elevations range from about 400 to $1800 \mathrm{~m}$. The base covers portions of the Big Delta and Mt. Hayes USGS quadrangles.

According to Jorgenson et al. (2001), the base originated as Station 17, Alaska Wing of the Air Transport Command, in 1942 to serve as a refueling stop and was reduced to inactive status in 1945. In 1948 the installation was reactivated for cold weather maneuvers, and it was named the Arctic Training Center in 1949. Most of the facilities were constructed during the 1950s, including the military's first nuclear power plant. Chemical and biological weapons were tested during the 1950s. Studies of Fort Greely vegetation and flora were conducted by Holmes and Benninghof (1957) who collected about 400 species of vascular plants. Under the BRAC-1995, Congress designated a portion of the Main Post to be closed and training activities to be realigned with Fort Wainwright. Fort Greely currently is used for artillery, mortar, and small arms firing, aerial gunnery, and platoon to brigade exercises and bivouacs because of the large area and the unique opportunities for cold weather testing, glacier training, mountaineering, river rafting, and ice-bridge construction. The U.S. Air Force 


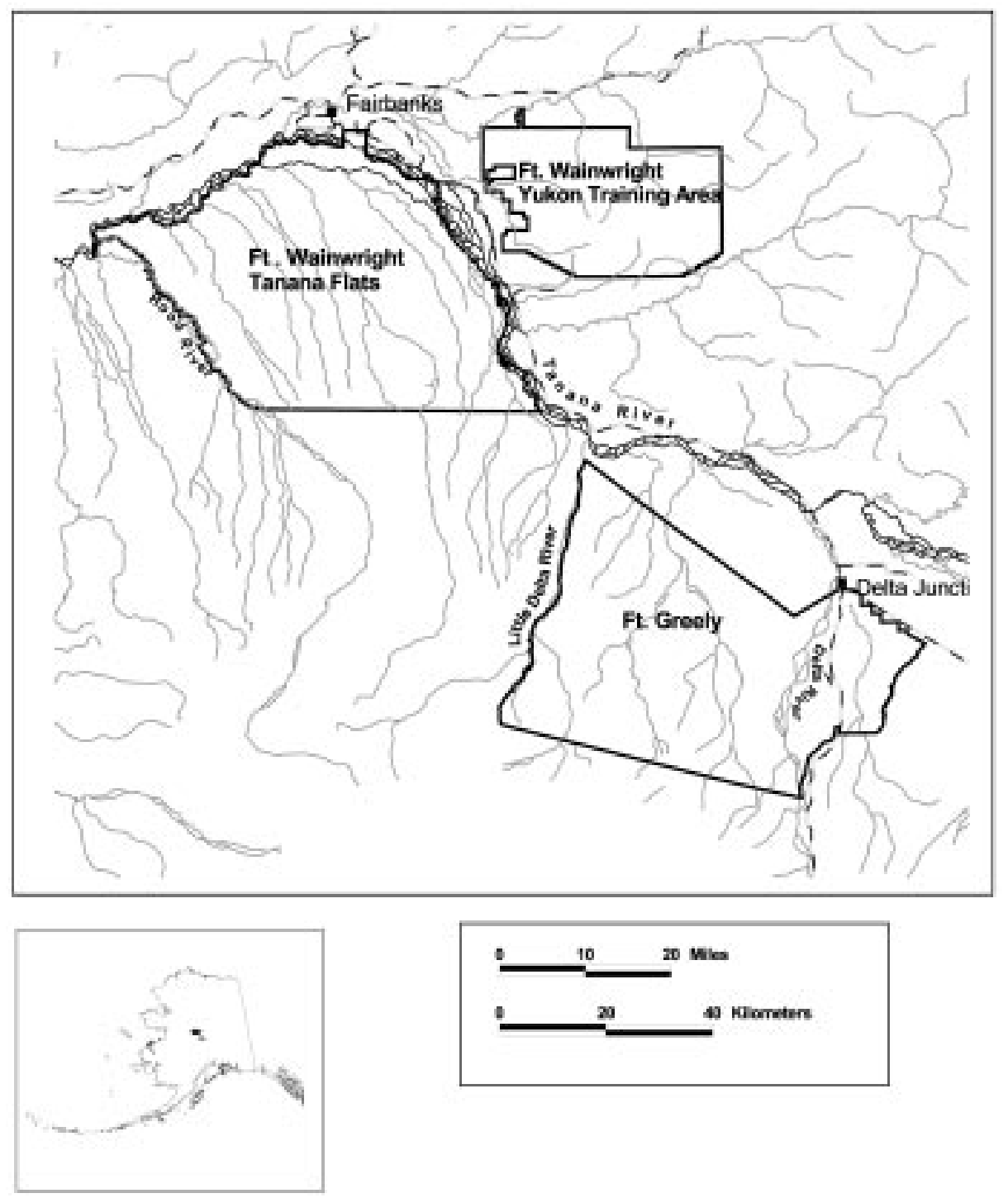

Figure 1. Fort Greely and Fort Wainwright military installations.

is a major user of Fort Greely and has delineated the Oklahoma/Delta Creek Impact Areas as the primary sites of military aircraft training. About 62,720 ha (156,800 acres) or $25 \%$ of the entire base is used as an Army artillery and Air Force impact area (Fig. 2)

\section{Climate}

The continental climate of interior Alaska has extreme annual temperature variations and relatively low precipitation. Although light winds are typical over much of the interior region, Fort Greely experiences strong gusty winds, particularly from the south (Benson 1972). According to U.S. Weather Bureau records (1937-98), the mean annual temperature is $-2.3^{\circ} \mathrm{C}$, with extremes ranging from -51 to $38^{\circ} \mathrm{C}$ (Nelson 1995). The mean monthly temperature is $15.6^{\circ} \mathrm{C}$ for July and $-19.9^{\circ} \mathrm{C}$ for January. The average annual precipitation is $297 \mathrm{~mm}$ and annual snowfall averages $178 \mathrm{~cm}$.

\section{Geomorphology and vegetation}

Jorgenson et al. (2001) described and mapped the geomorphology, vegetation, and ecosystems of Fort Greely using an Ecological Land Classification approach. They mapped geomorphic units, with 22 of them being fluvial, 3 being eolian, 4 being glacial, and 5 being organic classes. Glacial and eolian processes dominate, with the earlier Delta glaciation and the later Donelly glaciation producing the moraines and associated deposits of eolian sediments (Church et al. 1965, Péwé and Reger 1983). Jorgenson et al. (2001) also mapped five ecodistricts (Fig. 3) on the basis of physiography and climate associated with topography. Moun- 


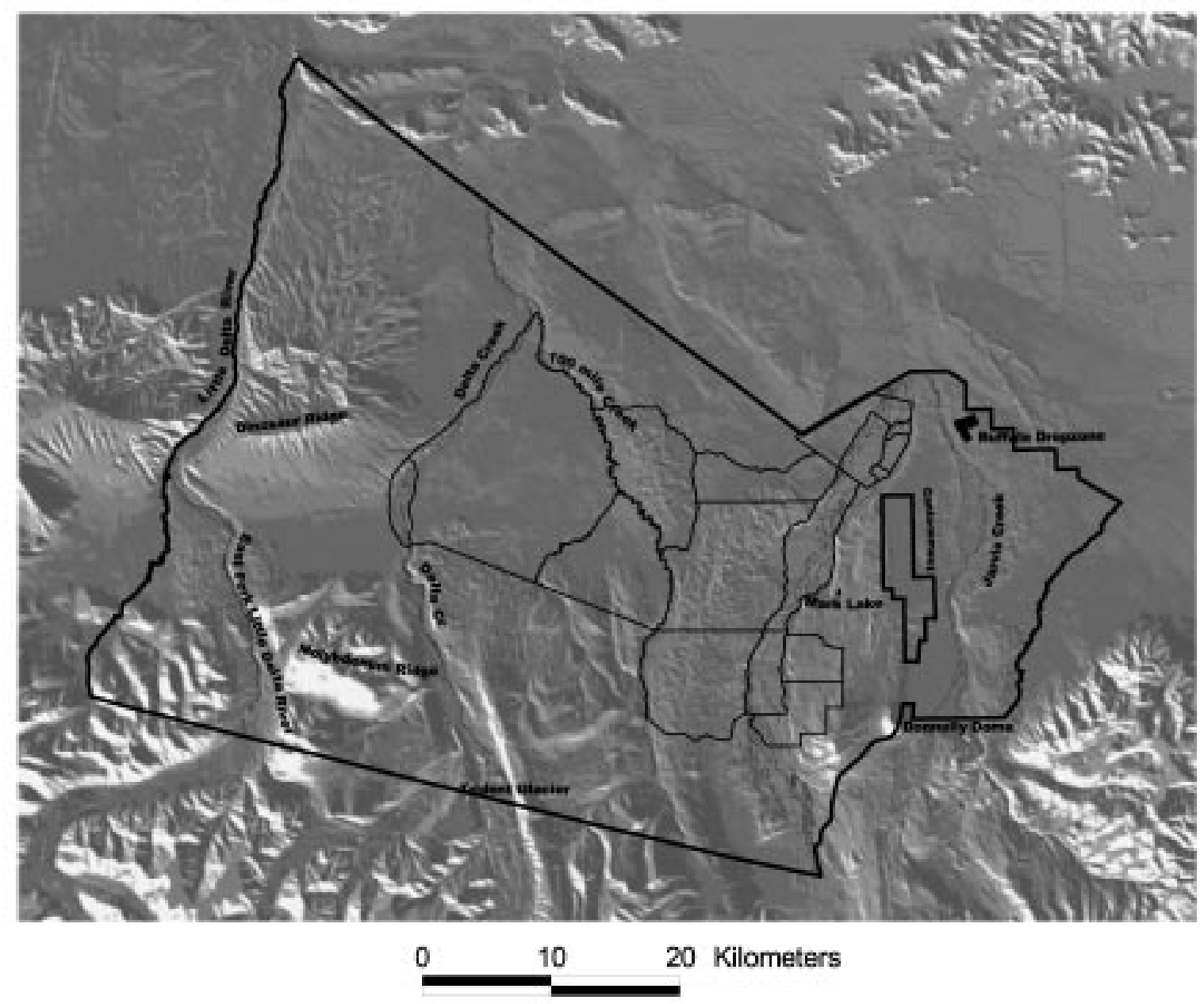

Figure 2. Topographic features of Fort Greely roads, cantonement (outlined), and impact areas.

tain areas (Hayes Mountain, Gakona Mountains) were above $900 \mathrm{~m}$ where treeline occurs, Highlands (Delta Highlands) ranged from 600-900 m, while lowland areas (Delta Lowlands) were below $600 \mathrm{~m}$. The four large floodplains crossing the base from south to north are mapped as the Middle Tanana Floodplain.

Jorgenson et al. (2000) classified and mapped 37 local ecosystems on the basis of a combination of physiography (i.e., alpine, lowland, riverine, etc.), moisture status, soils or substrate, and dominant vegetation growth form: $12 \%$ of the area is occupied by Alpine ecosystems (i.e., Alpine Rocky Moist Low Scrub), 20\% by Upland ecosystems (i.e., Upland Moist Low and Tall Scrub), 55\% by Lowland ecosystems (with Lowland Tussock Scrub Bog being the most common type covering $21 \%$ of the base), and $8 \%$ by Riverine ecosystems (i.e., Riverine Gravelly Barrens).

\section{Habitats}

Plant species are associated with particular habitats and communities that are determined by the soil mois- ture, soil chemistry and texture, temperature, wind, and snow cover. The most extreme habitats of wetness or dryness, or those with the lowest temperatures, often contain unique assemblages of species.

\section{Floodplains}

Braided river drainages are an important feature of the base (Fig. 4a). The more stable margins were dominated by tall alder and willow scrub communities, and large areas of open gravel bar were dominated by Dryas drummondii, legumes such as Hedysarum sp. and Oxytropus sp., and low scrub such as Salix glauca and Elaeagnus commutata. The endemic willow Salix setchelliana was found at most open gravel bar sites. Wet to moist, fairly stable sedge-forb meadows (such as site 38) were not common, though the vast majority of the Delta River Bar was closed because of unexploded ordinance and could possibly contain more of this species-rich habitat. Wind blown sand, encroaching on neighboring forest and scrub, was encountered on portions of Jarvis Creek. 


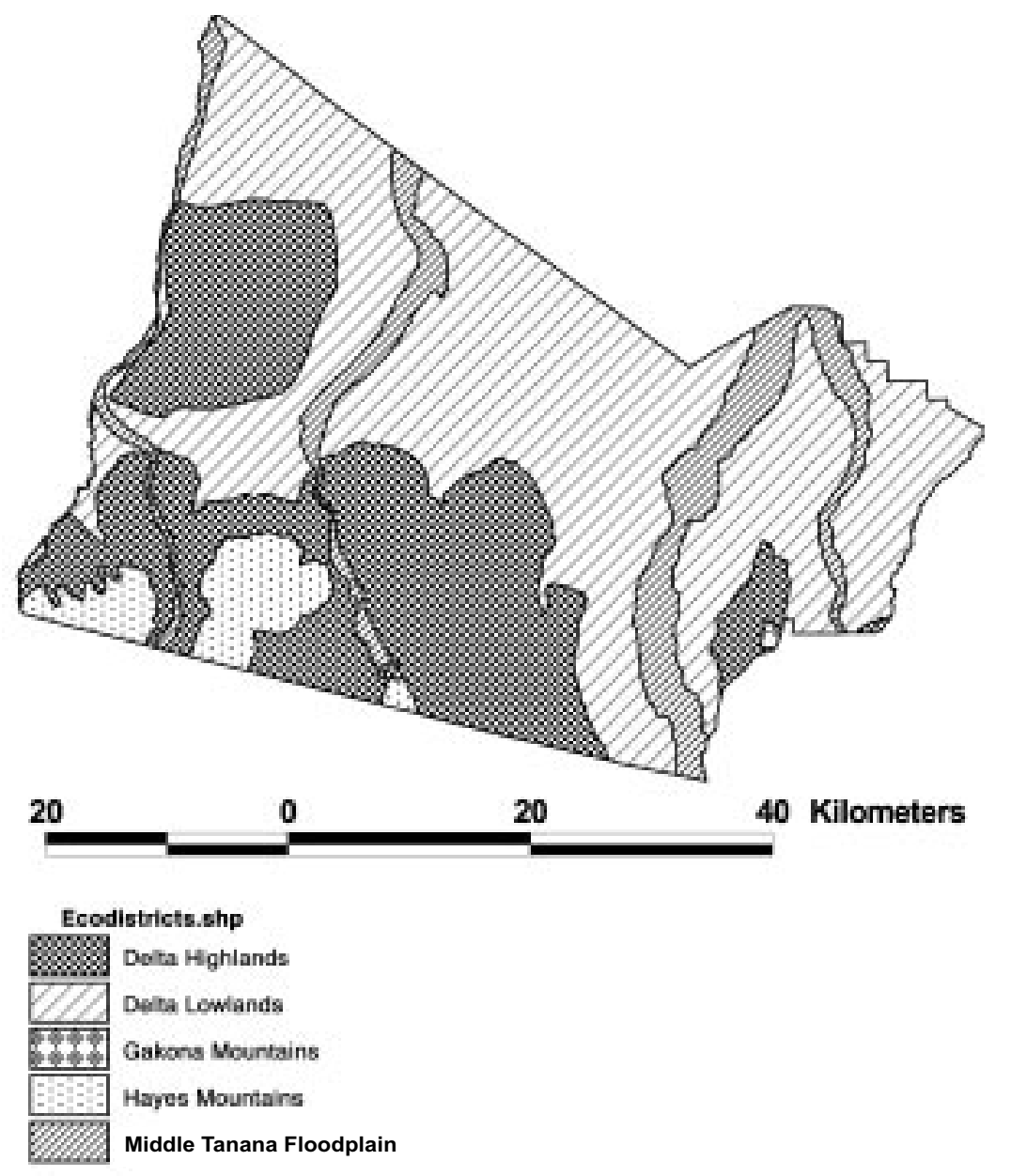

Figure 3. Major subdivisions of Fort Greely (ecodistricts) based on physiography from Jorgenson et al. (2000).

\section{Forests}

Large mosaics of closed and open-canopy broadleaf forests of aspen and paper birch, and mixed white spruce-broadleaf forests, cover much of the northeastern section of the base (Fig. 4b). White spruce-lichen woodlands covered large areas of the Jarvis Creek lowlands in the southeast. Lowland forests and woodlands were represented by balsam poplar stands in welldrained alluvium, white spruce forests on well-developed mesic terraces and some moraines, and black spruce muskegs at poorly drained sites. Tamarack was present but not found to be a major component of lowland areas.

\section{Burns}

Both uplands and lowlands have been greatly influenced by fire (Fig. 4b). Jorgenson et al. (2001) estimated that $59 \%$ of Fort Greely $(153,812$ ha) has been burned since 1950, although a substantial portion of this burned area has burned more than once. Many sites showed varying degrees of recovery from fires occurring within the last decade.

\section{Alpine}

Treeline in the mountains and highland plateaus on Fort Greely occurs at about $900 \mathrm{~m}$. The southern portions of the base contain small mountains and the foothills of the Alaska range (Fig. 4c). In the southwestern corner of the base, the Molybdenum Ridge group, mostly granitic rock with some sedimentary rock on the northern side, supported a wide variety of alpine habitats. Low birch and dwarf ericaceous scrub dominated large areas. Ridge tops supported Dryas octopetala-lichen-dwarf willow communities, and drainages contained tall riparian communities of willow and alder. They supported many species of the genera Draba, Saxifraga, Senecio, and Minuartia.

Additionally, the terminus of the Trident Glacier is 


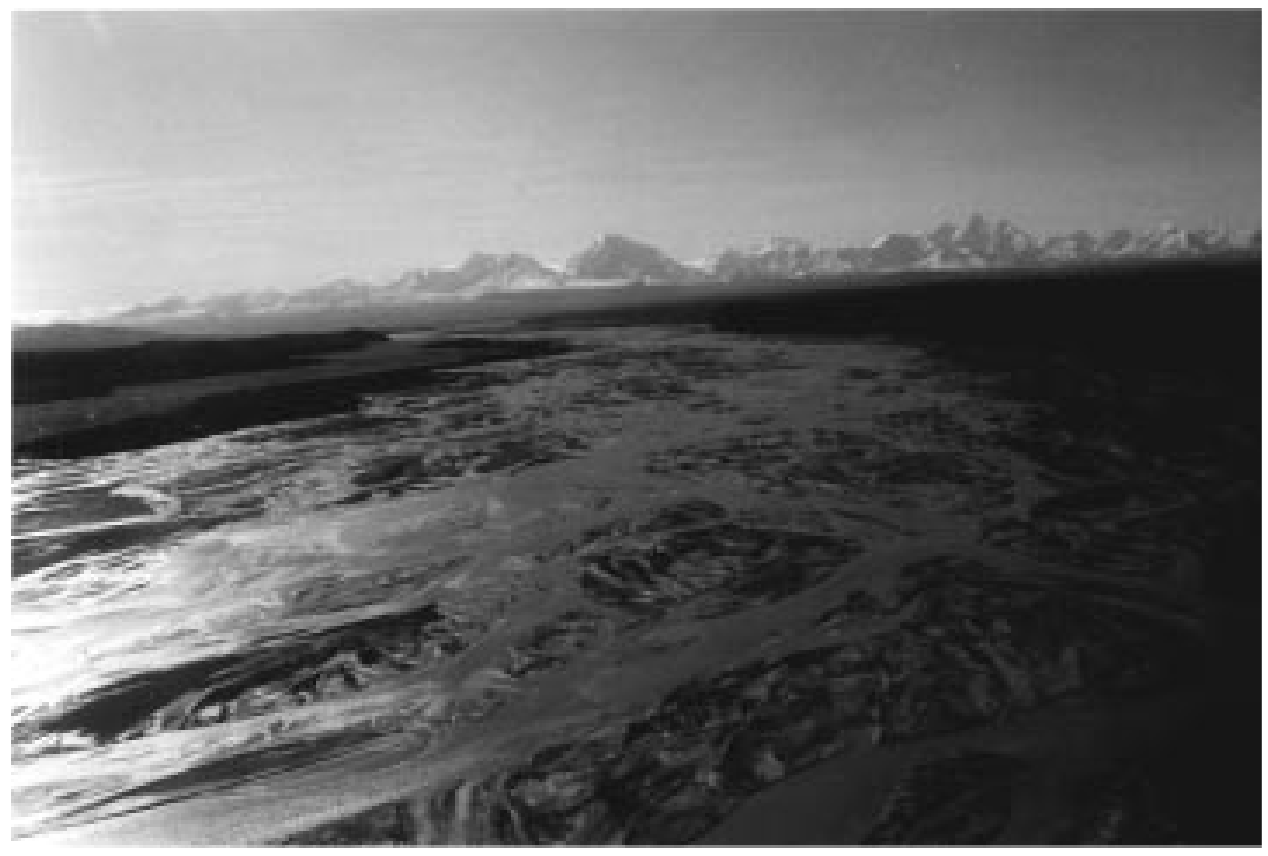

a. Aerial view south down Delta River floodplain on Fort Greely with the Alaska Range mountains in the background.

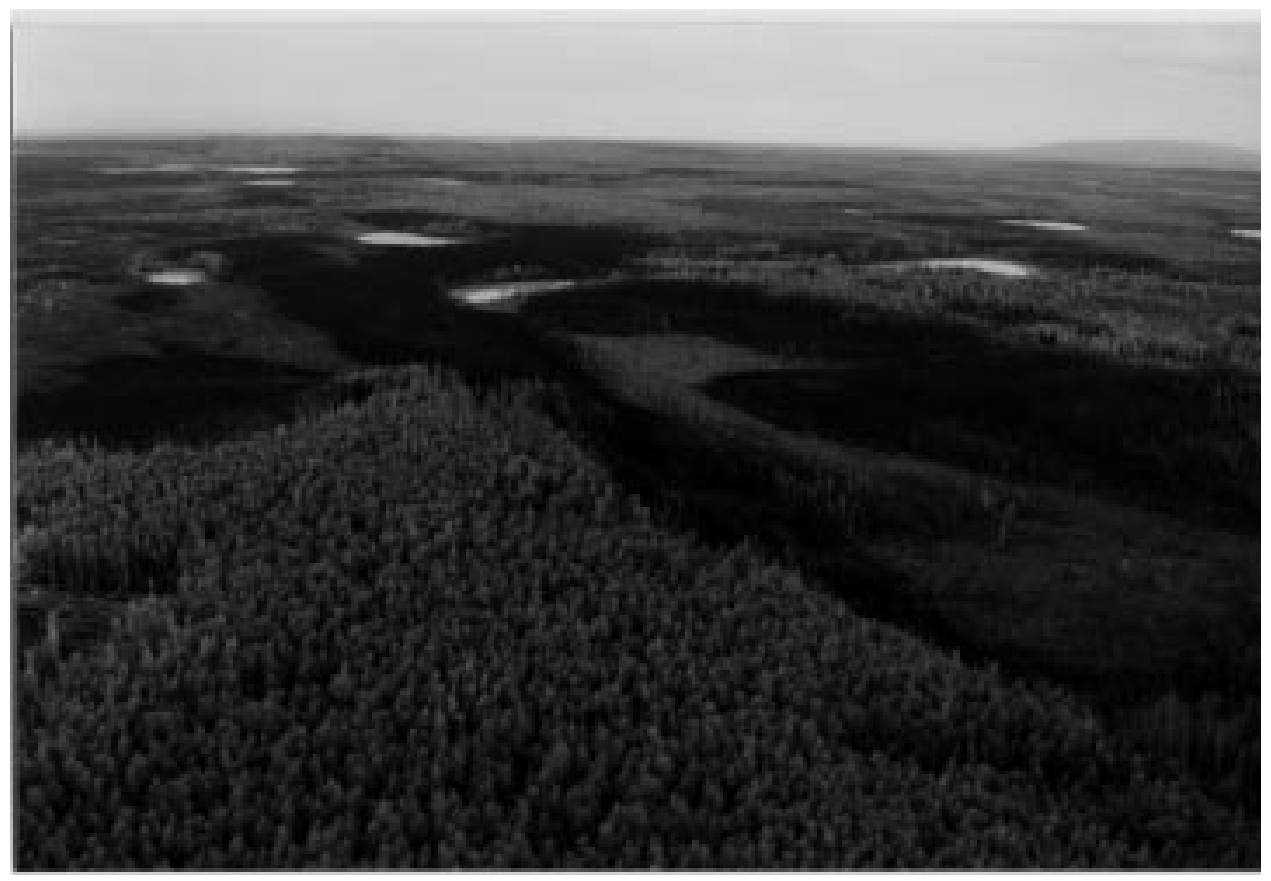

b. Aerial view of birch forest on glacial moraine with kettle ponds. Also visible is a portion of the 1999 Carla Lake burn.

Figure 4. Major habitats and divisions of Fort Greely. 


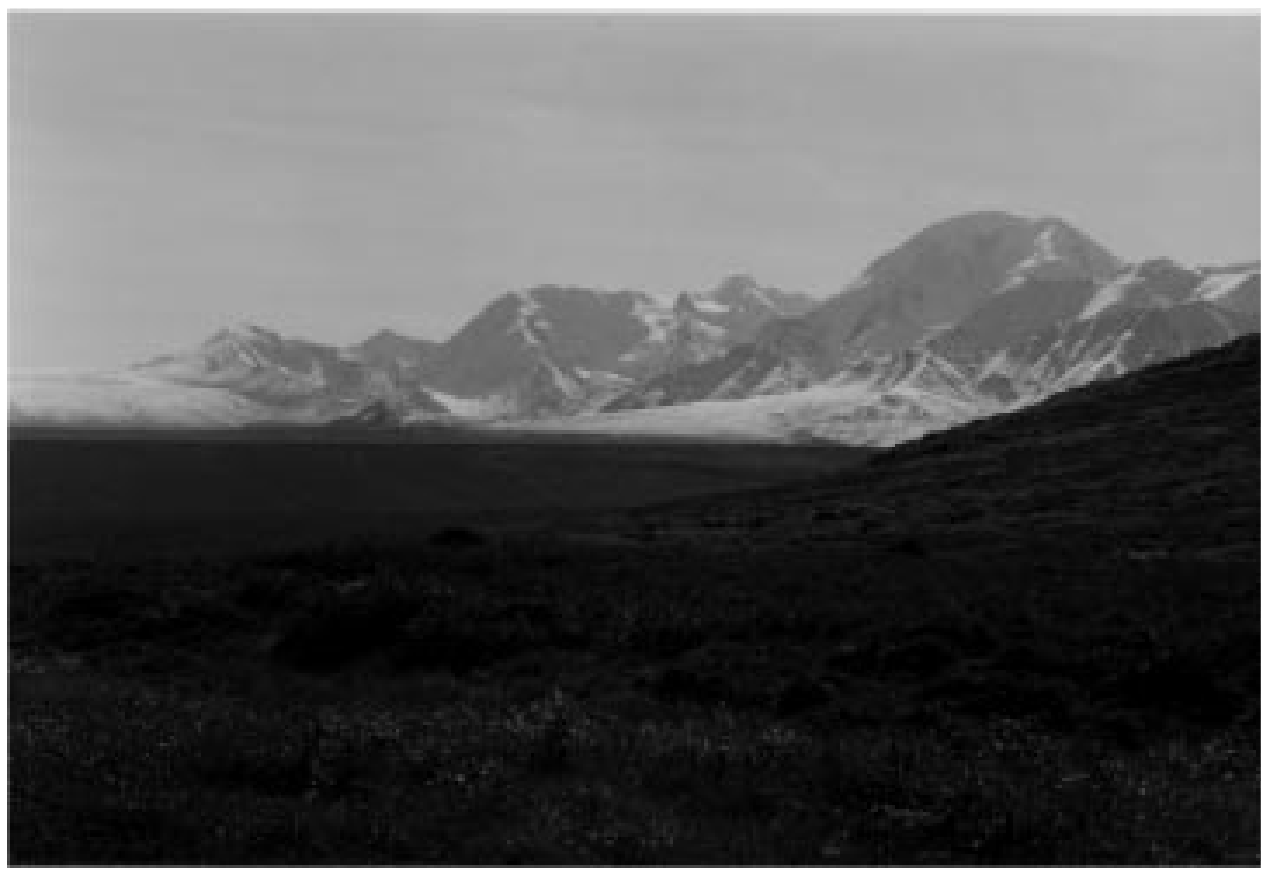

c. View southeast from alpine area near Molybdomum Ridge toward Alaska Range and Trident Glacier in background.

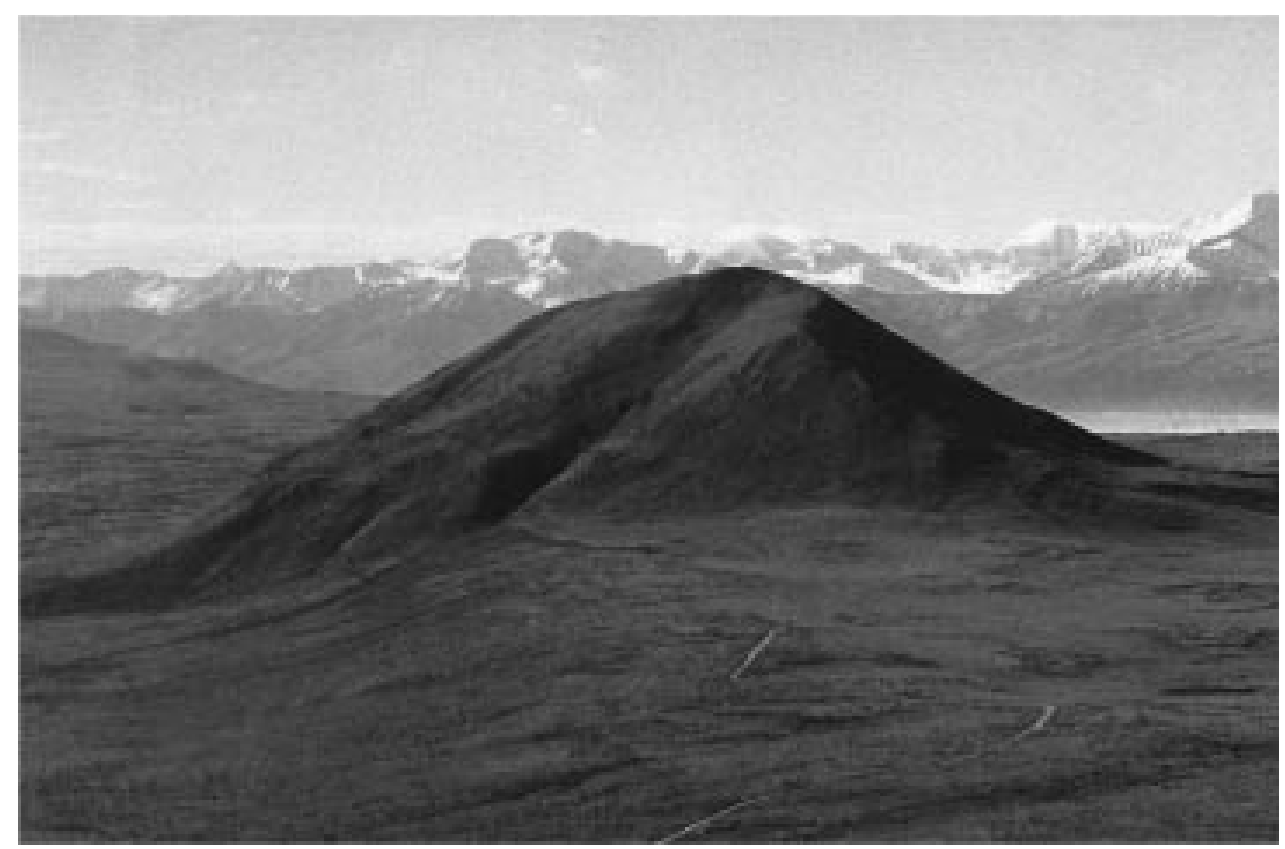

d. Aerial view south over Fort Greely of Donelly Dome (an outlying monadnock of the Alaska Range), which has a number of alpine species on its summit at $1300 \mathrm{~m}$ (3910 ft).

Figure 4 (cont'd). Major habitats and divisions of Fort Greely. 


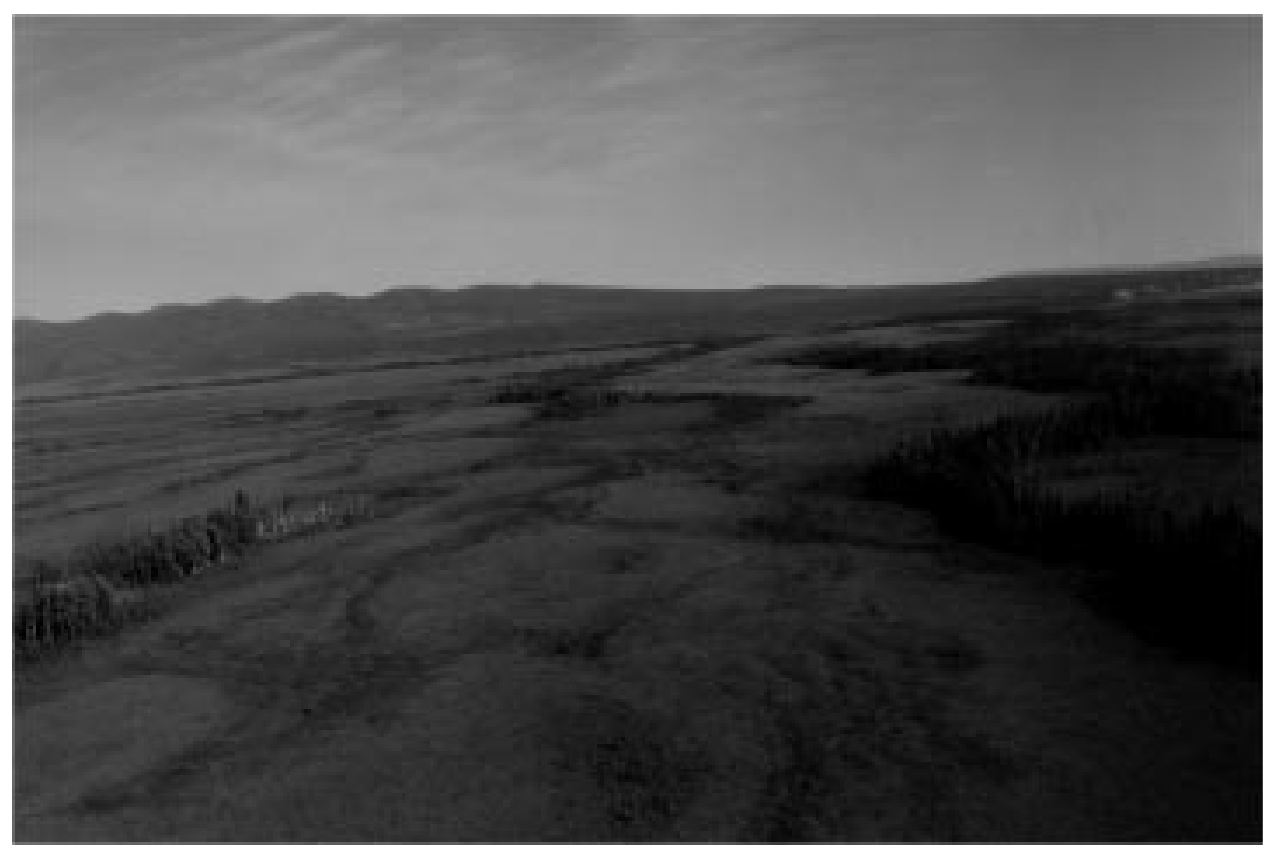

e. Aerial view of lowlands with spruce forest along streams and tussock shrub vegetation on flats between the streams.

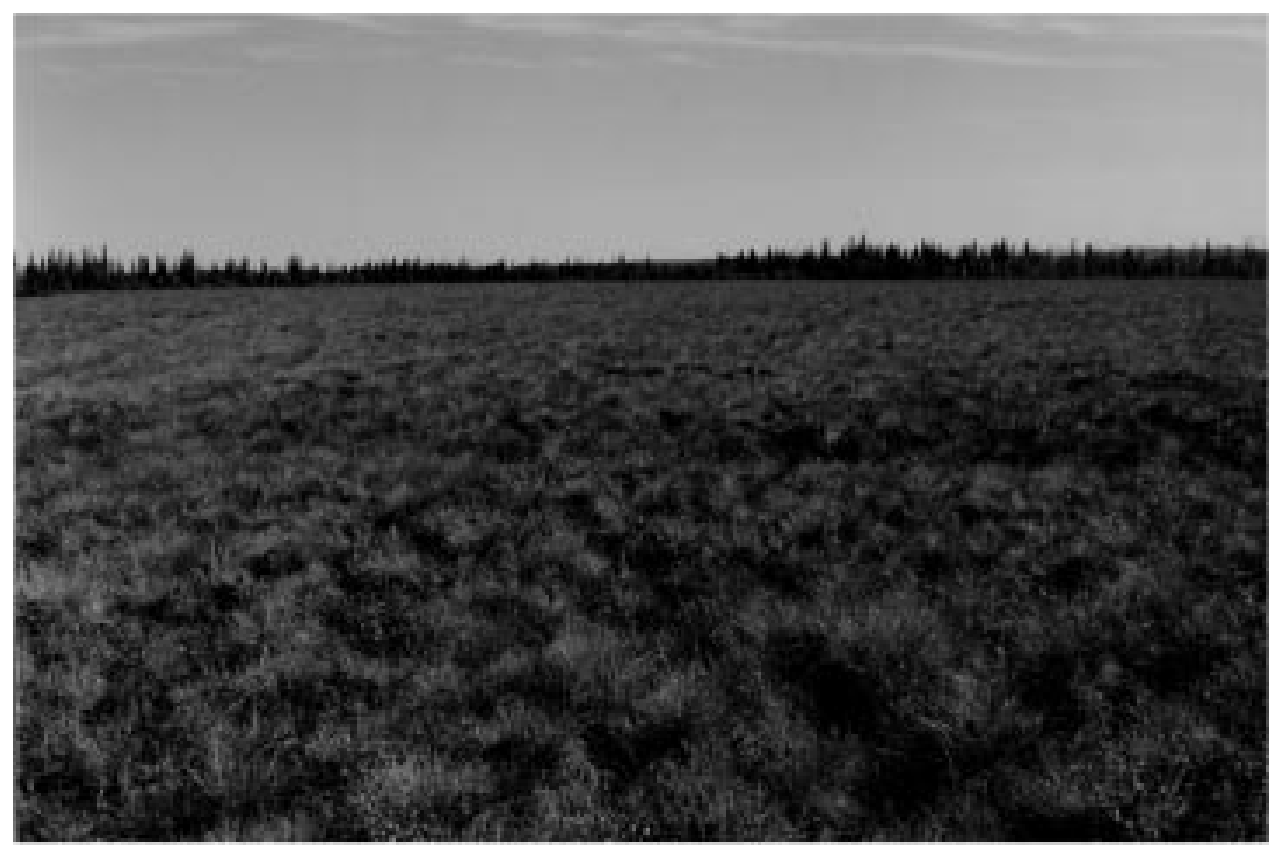

f. Close-up of Lowland tussock scrub vegetation, which covers about $20 \%$ of Fort Greely.

Figure 4 (cont'd). 
within the boundaries of the base (Fig. 4c). It is an active glacier, with a thinly vegetated (though distinctive) terminal moraine.

The largest feature of the southeastern corner of the base is Donnelly Dome (Fig. 4d). It is an isolated monadnock of schist, and has well developed alpine communities. Its proximity to the Richardson Highway makes it a heavily used recreation destination, and several trails lead to its summit.

\section{Wet habitats}

Lichvar and Sprecher (1999) delineated the wetlands on Fort Greely. Large expanses of the western half of the base were covered in tussock wetlands, dominated by Eriophorum vaginatum, shrubs such as alder, and Sphagnum moss (Fig. 4e and f). Also common were low birch, willow, open tall alder, and some sweetgale scrub-shrub wetlands. Numerous kettle ponds exist on the glacial moraines (Fig. 4b). Many of these ponds have a meadow margin of Carex saxatilis and Calamagrostis canadensis. Well developed Sphagnum bogs are rare. Mark Lake (site 34) was one of the few lakes surveyed that supported a diverse aquatic community.

\section{Dry sites}

On Fort Greely, xeric or dry bluffs and slopes were found extensively bordering the major river floodplains (Fig. 4a) and on the south-facing moraines of the Delta and Donnelly glaciation. The largest and most extensive of these dry slopes were within the firing range closures and, therefore, inaccessible. Most dry, southfacing moraine slopes were fairly small and more similar to dry alpine communities than the steppe communities encountered at Fort Wainwright. On Fort Greely, these were dominated by communities of Calamagrostis purpurascens, Potentilla hookeriana, and Erigeron cespitosus, with a high percentage of the cover being Stereocaulon lichen, Arctostaphylos uva-ursi, and Saxifraga tricuspidata. An unusual feature of many of these dry slopes was a shrub-like component of "krumholz" aspen — dwarfed and gnarled trees, less than a meter high-representing approximately 5-20\% of the cover.

\section{METHODS}

\section{Preliminary checklist development}

A preliminary checklist of vascular plant species expected to be found on Fort greely was prepared using the range maps in The Flora of Alaska (Hulten 1968) and Alaska Trees and Shrubs (Viereck and Little 1972) and from a list of specimens from the University of
Alaska Museum-Herbarium (ALA) that were collected in the Big Delta and Mount Hayes Quadrangles between $63^{\circ} 40^{\prime} \mathrm{N}$ and $64^{\circ} 10^{\prime} \mathrm{N}$ (Batten 1997). This working list was used to help determine collection sites and focus the survey efforts.

\section{Subdivision of base for site selection}

The five ecodistricts recognized by Jorgenson et al. (2001) provided the broadest subdivision of the base and the areas we hoped to visit during the inventory (Fig. 3). These were further divided into 25 ecosubdistricts based on vegetation, soils, permafrost characteristics, water bodies, and fauna. These divisions were used in planning field trips to adequately cover the major landscape and floristic features of the base. Collections were made in as many of these subdivisions as could be accessed, and in as many vegetation types and specialized habitats within those ecosubdistricts as was logistically possible. Specific survey sites were identified using color infrared aerial photography $(1: 60,000)$, topographic maps, and consultation with biologists conducting the Land Condition Trend Analysis (LCTA) project.

\section{Site access and collecting}

Preliminary collections were begun by ABR, Inc., in 1996 (Jorgenson et al. 2001) along several transects sampled for vegetation and soils. In 1998 ABR sampled vegetation along additional transects on 74 sample plots and, in addition, added 89 ground-reference plots at sites not represented along these transects. In August 1998 they also visited 126 map verification plots to assist in construction of a vegetation map. Figure 5 shows the location of all of these sites from 1996 to 1998. Although plant collections and floristic inventories were not conducted at all of these sites, they provide a record of site visits by botanists.

Inventories were continued during the middle of $\mathrm{Au}$ gust 1997 by R. Lichvar while he was delineating wetlands on Fort Greely. Finally, the bulk of the collection was made during the first two weeks of July and all of August 1998 by M. Duffy. All sites where collections were made are shown in Figure 6 and a list of the site names and numbers corresponding with this map are provided in Table 1.

Special attention was given to obtaining as broad a representation of survey sites as possible within two distinct limitations: four-fifths of the base is separated from the road system by the Delta River, and approximately one-quarter of the base is off-limits owing to its use as artillery and bombing ranges (Fig. 5 and 6). In addition, the cantonment area on Fort Greely (Fig. 2) was specifically excluded from the floristic inventory, unlike the inventories on Forts Richardson and Wainwright. 


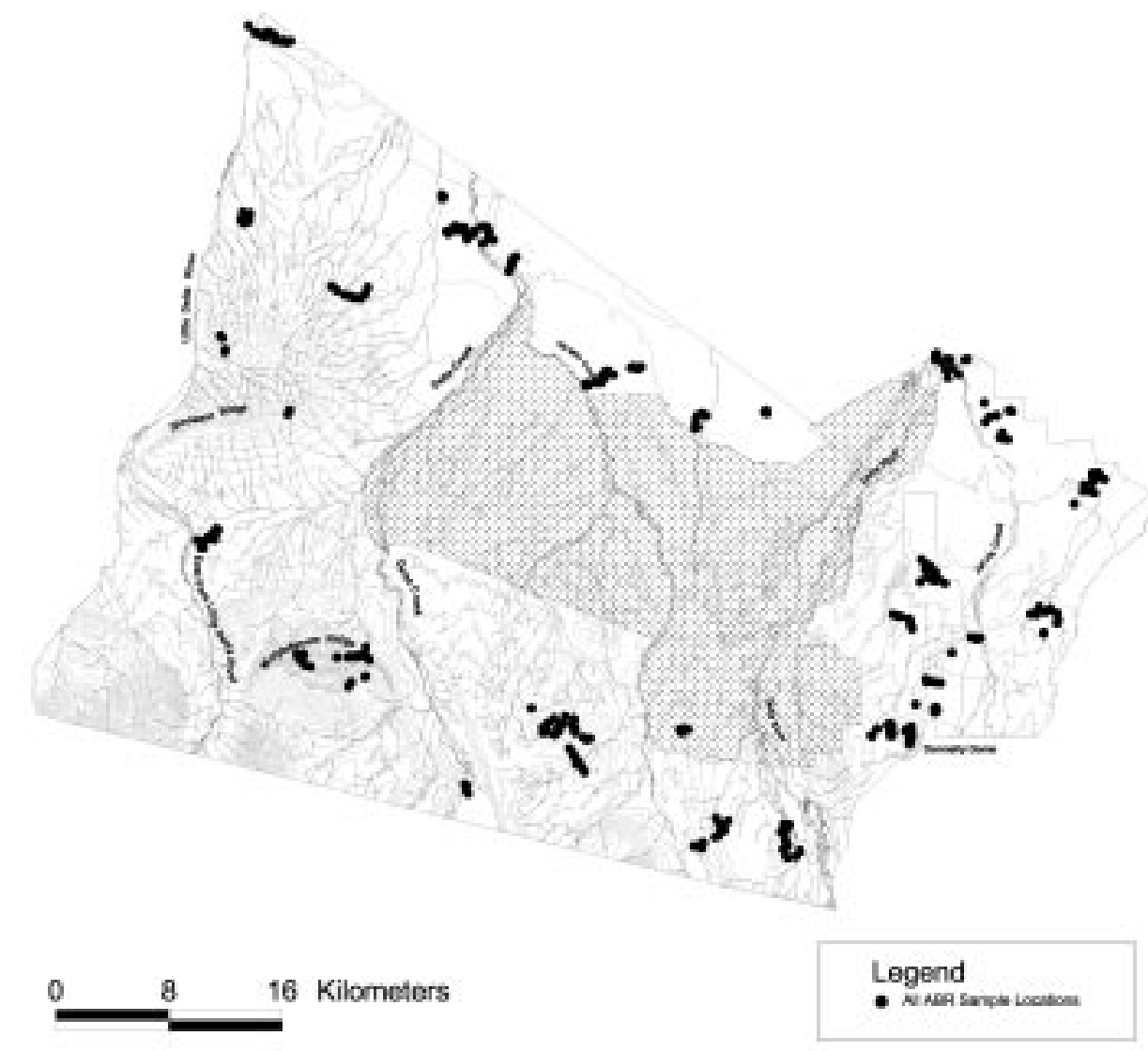

Figure 5. Sites where ABR, Inc., conducted an ecological land survey in 1996 and 1998 on Fort Greely (Jorgenson et al. 2001). Shaded areas are impact ranges.

The portion of Fort Greely east of the Delta River is bisected by the Richardson Highway, and has numerous roads and dirt tracks that allowed for access by fourwheel drive and all-terrain vehicles, even to remote areas, where inventories could be carried out on foot. The greater portion of the base, west of the Delta River, was accessed using helicopter support. A remote camp was set up on Molybdenum Ridge for several days of collecting in early August 1998. Numerous brief surveys were conducted during trips shared with biologists working on other projects in late August 1998.

Inventory sites where collections were made were assigned a number and plotted as a point onto the two Defense Mapping Agency 1:50,000-scale topographic maps. In addition a hand-held GPS unit was used to record coordinates and navigate to sites. The plotted locations or GPS coordinates were digitized and imported into Arcview GIS to produce maps showing inventory sites (Fig. 5 and 6, Table 1).

\section{Identification and verification of specimens}

Collections were tentatively identified in the field using Hulten (1968). Specimens collected in 1997, and some of the material collected by ABR, were reviewed by M. Raynolds in September 1997. Specimens collected during 1998, and additional ABR material, were reviewed by M. Duffy in 1998 and 1999 using Hulten (1968), Cody (1996), and other references, as well as collections archived at ALA and the Gray Herbaria at Harvard University in Cambridge, Massachusetts. Rare and difficult taxa were verified by C. Parker at ALA in March 1999. Other monographs and flora publications consulted include Hitchcock et al. (1955-1969), Porsild (1974), Welsh (1974), Brayshaw (1985), Aiken and Darlyshire (1990), Williams and Lipkin (1991), U.S. Soil Conservation Service (1994), and Aiken et al. (1996).

\section{Botanical nomenclature}

As with the inventories of Forts Richardson and Wainwright, nomenclature for this report follows The University of Alaska Museum Plants database (ALABASE), which is based on the most recent taxonomic revisions of the Alaska flora (Murray et al. 1994) and the Flora of North America project (FNAEC 1993). Some plant names, therefore, differ from those used in Hulten (1968) and his supplement (Hulten 1973). In 


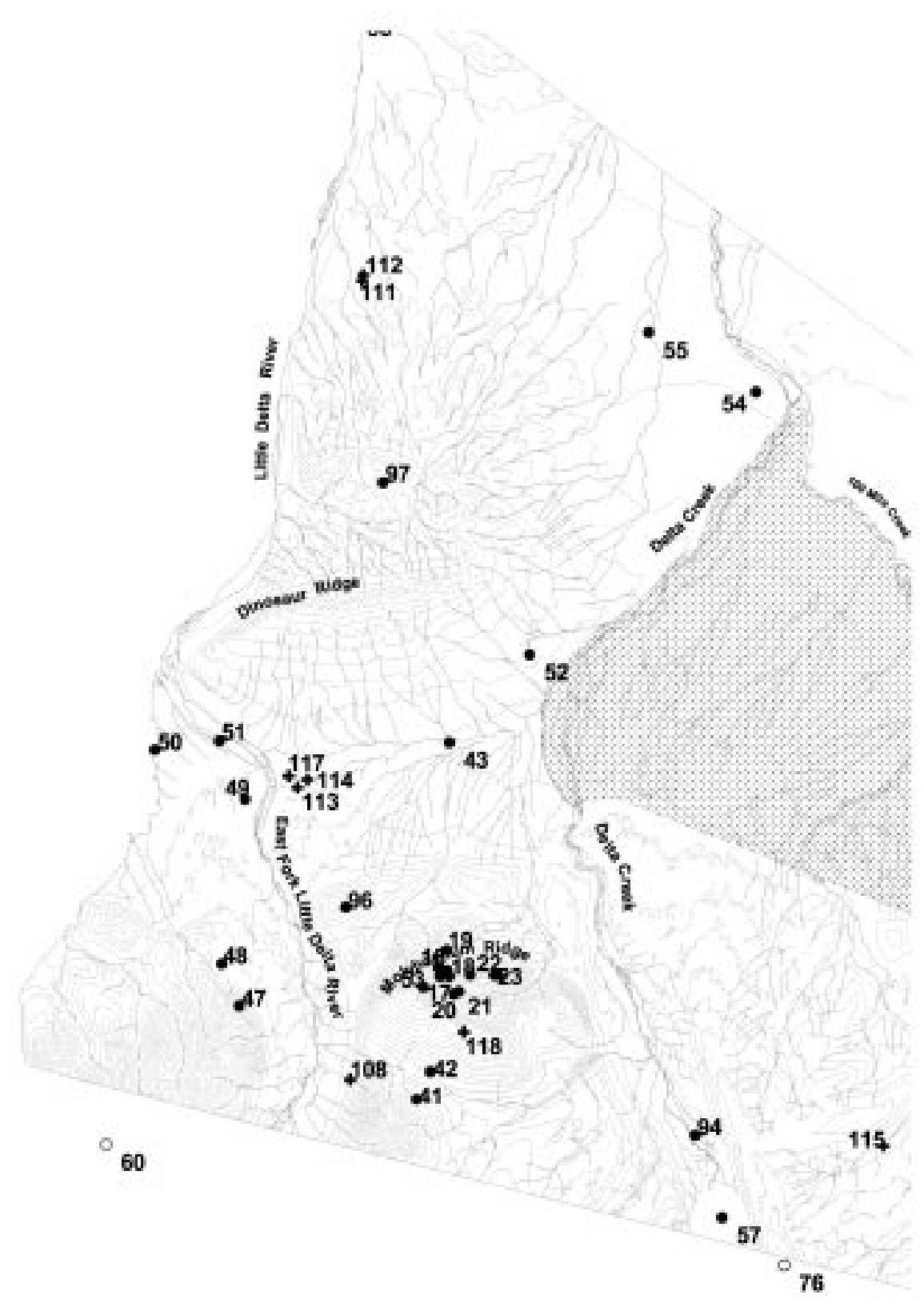

a. Western side of Fort Greely.

Figure 6. Locations of floristic inventory sites where ABR, Inc., M. Duffy, and $R$. Lichvar collected vascular plants or inventoried vascular plant species, or both. (Site numbers are described in Table 1.)

these cases the name given in Hulten follows in brackets in Appendices A and B. In some cases there are no clear matches to the treatments given in Hulten (for example, the genus Elymus), and in one case a species was not found in Hulten because it has only recently been known to be in the area (Potamogeton obtusifolius). A more up-to-date source, Cody's Flora of the Yukon Territory (1996) is very useful for the Fort Greely area. Two other sources can be used to determine current synonyms: Kartesz (1994) and the NRCS Plants database, which is available over the Internet at http://plants.usda.gov. 

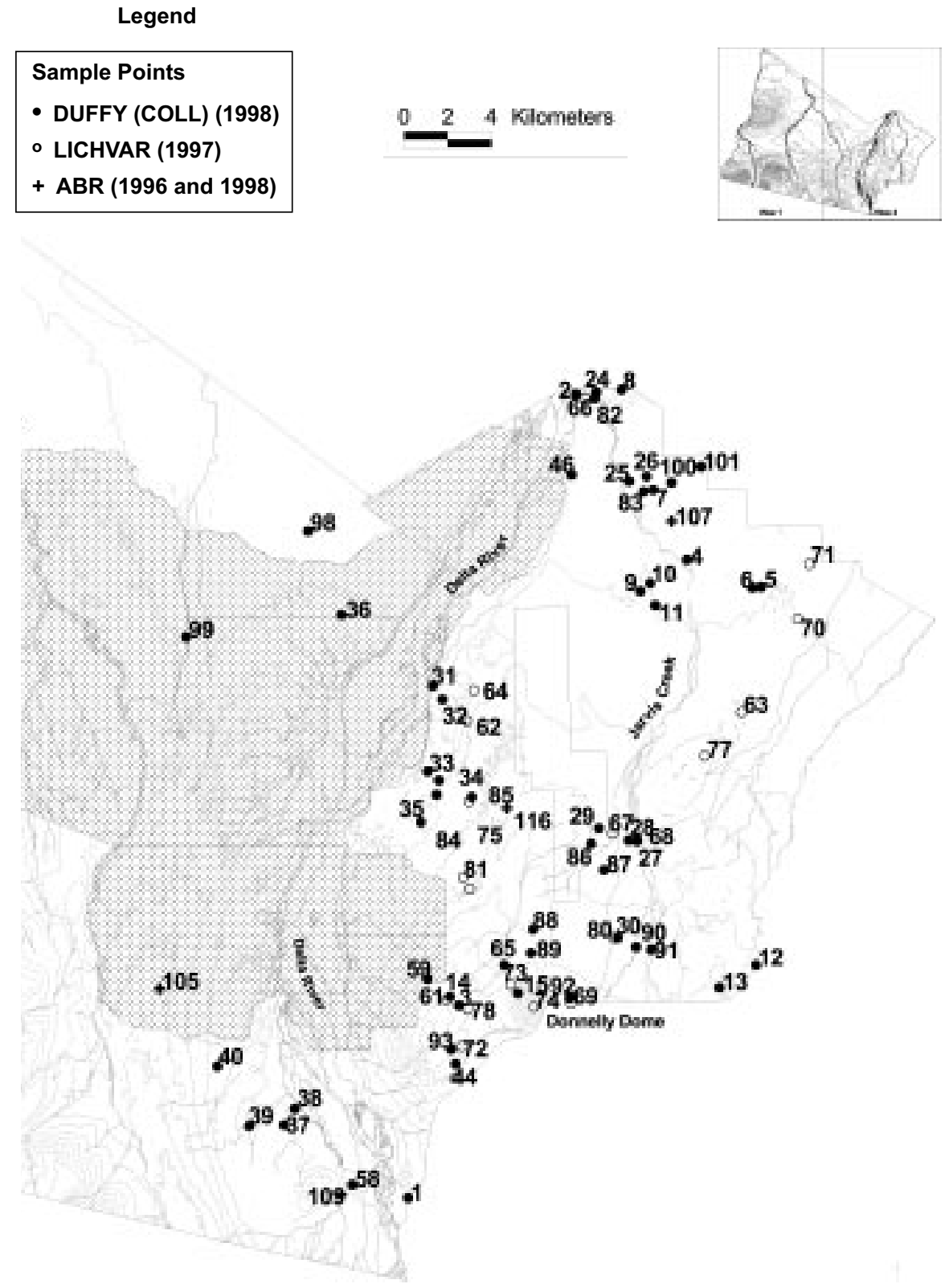

b. Eastern side of Fort Greely.

Figure 6 (cont'd).

\section{RESULTS}

\section{Inventory sites}

Collections were made at 22 sites in 1997 by R. Lichvar and at 59 sites in 1998 by M. Duffy. An additional 20 sites were surveyed by Duffy in 1998 where no collections were made, for a total of 101 sites (Table 1). Collections from 16 ABR transects were also used for the species list. All site locations are shown on the maps in Figure 6, with sites noted as numbered points described in Table 1. Two sites fell just outside the boundaries of Fort Greely, but species collected at those sites were all observed within base boundaries. 
Table 1. Floristic inventory observation and collection sites located on Figure 6 maps.

\author{
Site /map \\ number \\ Site name
}

M. Duffy collection sites August 1998

Delta River gravel bar, east side

Jarvis Creek-Delta River confluence

Donnelly radio tower 1

Jarvis Creek, between Buffalo and

Eddy DZ

33-Mile Loop Road east of Eddy DZ 1

33-Mile Loop Road east of Eddy DZ 2

Buffalo DZ, center

33-Mile Loop Road at the radio tower

Canister Lake

ridge east of Canister Lake

wet meadow southeast of Canister Lake

Granite Creek

Granite Lakes

Donnelly radio tower 2

Donnelly Dome, west side

Molybdenum Ridge 1

Molybdenum Ridge 2

Molybdenum Ridge 3

Molybdenum Ridge 4

Molybdenum Ridge 5

Molybdenum Ridge 6

Molybdenum Ridge 7

Molybdenum Ridge 8

dunes northeast of Jarvis Creek bridge

Bear Crossing

Buffalo DZ north

12-Mile Crossing

muskeg west of 12-Mile Crossing

ridge west of 12-Mile Crossing

road southeast of old radar domes

bluffs at OP6

pond near OP6

bluffs at OP7A

Mark Lake

meadow east of Twin Lakes

Nevada Lakes

Minnesota Training Area 1

Delta River gravel bar, west side 1

Minnesota Training Area 2

Minnesota Training Area 3

saddle on north flank of Patton Mt.

saddle between Patton Mt. and

Molybdenum Ridge

wet meadow south of Deadhorse Creek

Weasel Lake

Dome Road

Richardson Highway rest stop

ridge north of MacArthur Mt.

Dice Lakes

pond $1 \mathrm{~km}$ northeast of Claudell Lake

Buchanan Creek

East Fork of the Little Delta River

Hillbilly Lake

Molybdenum Ridge 9

muskeg $1 \mathrm{~km}$ west of Delta Creek

woods $3 \mathrm{~km}$ west of Delta creek

Little Delta River
Table 1 (cont'd).

Site /map

number

Site name

$57 \quad$ Trident Glacier

58 Delta River gravel bar, west side 2

59 Donnelly radio tower 3

R. Lichvar collection sites 1997

603 miles southwest of the peak of

MacArthur Mountain

61 approx. 2 miles west of Donnelly Dome

$62 \quad$ Bolio Lake

63 Guitar Lake area

64 inlet side of Bolio Lake near road

crossing

$65 \quad J$ Lake

66 Jarvis Creek bridge

67 Jarvis Creek floodplain, north or 12-

Mile Crossing

68 Jarvis Creek, 12-Mile Crossing

69 Jarvis Lake Road

70 just north of Dall Lake

71 Mary Lake

72 north of Weasel Lake

73 north side of Donnelly Dome

74 northeast side of Donnelly Dome

$75 \quad$ North and South Twin Lakes

76 Ridge east of Trident Glacier

77 southweat of String Lake

78 trail side northeast of Weasel Lake

$79 \quad$ Weasel Lake area

80 West of Ober Creek

$81 \quad$ Wishbone Lake area

Observation Sites visited in 1998 by M. Duffy, but where no collections where made

82 Jarvis Creek, southeast of bridge

83 aspen forest west of Buffalo DZ

$84 \quad$ Big Lake

$85 \quad$ Twin Lakes

86 lichen forest north of Fox DZ

87 forest east of Donnelly Assault Airfield

$88 \quad$ pond west of Dome Road

89 wet meadow south of Dome Road

90 Ober Creek, east of old radar domes

91 Jarvis Creek, east of old radar domes

92 small pond south of Bear DZ

93 radio tower north of Weasel Lake

94 Delta Creek, north of Trident Glacier

$95 \quad$ Molybdenum Ridge 10

96 ridge north of York Saddle

97 ridge north of Dinosaur Ridge

98 meadow $1 \mathrm{~km}$ south of Diamond Lake

99 burned meadow, east end of Kansas

Lakes Impact Area

100 Buffalo DZ east

101 road east of Buffalo DZ

ABR, Inc., collection sites 1996 and 1998

102 ridge at northern tip of reservation

(G10.10a) 
Table 1 (cont'd).

\begin{tabular}{|c|c|}
\hline $\begin{array}{l}\text { Site /map } \\
\text { number }\end{array}$ & Site name \\
\hline 103 & $\begin{array}{l}\text { bluff; ridge at northern tip of reservation } \\
\text { (G10.21) }\end{array}$ \\
\hline 104 & $\begin{array}{l}\text { lower Little Delta River; abandoned } \\
\text { floodplain (G10.22) }\end{array}$ \\
\hline 105 & $\begin{array}{l}\text { lateral moraine east of Duluth Lake } \\
\text { (G16.01) }\end{array}$ \\
\hline 106 & Bear Lake moraine (G18.O2) \\
\hline 107 & $\begin{array}{l}\text { approximately } 2 \mathrm{~km} \text { southeast Buffalo } \\
\mathrm{DZ} \text { (G23.01) }\end{array}$ \\
\hline 108 & $\begin{array}{l}\text { Richardson Highway northeast of } \\
\text { Donnelly Dome (G41 road) }\end{array}$ \\
\hline 109 & southern end Buffalo Hill (G43.17) \\
\hline 110 & $\begin{array}{l}\text { central-northern ridge line Molybdenum } \\
\text { Ridge (G5.01) }\end{array}$ \\
\hline 111 & $\begin{array}{l}\text { southwest of 4-Square Lakes } 1 \text { (transect } \\
\text { 1) }(\mathrm{P} 1.04 \mathrm{~A})\end{array}$ \\
\hline 112 & $\begin{array}{l}\text { southwest of 4-Square Lakes } 2 \text { (transect } \\
\text { 1) (P1.07) }\end{array}$ \\
\hline 113 & $\begin{array}{l}\text { moraine at Gnat Lake (transect 2) } \\
(\mathrm{P} 2.03)\end{array}$ \\
\hline 114 & $\begin{array}{l}\text { lake edge; moraine at Gnat Lake } \\
\text { (transect 2) (P2.09) }\end{array}$ \\
\hline 115 & $\begin{array}{l}\text { beaver-dammed creek bottom west of } \\
\text { Serpent Lake (transect 3) (P3.06) }\end{array}$ \\
\hline 116 & $\begin{array}{l}\text { moraine east of Big Lake (pond) } \\
\text { (transect 6) (P6.09) }\end{array}$ \\
\hline 117 & $\begin{array}{l}\text { pond edge moraine at Gnat Lake } \\
\text { (BJ2.2) }\end{array}$ \\
\hline 118 & south side Molybdenum Ridge \\
\hline
\end{tabular}

\section{Vascular plant collections}

A total of 723 collections were made during 1997 and 1998: 164 in 1997 and 559 in 1998. On the base, 497 taxa of vascular plants, representing 64 families and 198 genera, were documented. A species list for the Fort Greely survey was compiled and is presented in Appendices A (listed alphabetically) and B (listed by family). The 497 species and subspecies documented during this survey represent approximately $26 \%$ of the 1960 taxa listed in Hulten (1968).

\section{Collections at ALA}

The list of species represented by collections in the University of Alaska Museum-Hebarium (ALA) from the Mt. Hayes and Big Delta 1:250,000 USGS quadrangles was consulted. Six taxa from this list were collected on Fort Greely by Holmes and Benninghoff (1957) but were not found during this inventory (Woodsia glabella, Eritrichium splendens, Polemonium pulcherrimum, Pyrola grandiflora, Salix barclayi, and
Sparganium hyperboreum). These six species are included in the species list in Appendices A and B. In addition, 59 taxa were represented on the original Herbarium list but not collected on Fort Greely (App. C). These were also not collected during this inventory, but they may be present on the base.

\section{DISCUSSION}

\section{Distribution of inventory sites}

Although it was not possible to collect in the large central impact areas of Fort Greely, fairly good coverage of the major regions and habitats was obtained. Of the inventoried sites, 36 were west of the Delta River, and 65 were on the eastern side (Fig. 6). All five of the major ecodistricts mapped by Jorgenson et al. (2000) for Fort Greely were visited (Fig. 3). Although collection sites were well distributed geographically, no collections were made during June and some early flowering species may have been missed.

\section{Rare vascular plant species records}

None of the plants found during the survey are currently listed by the U.S. Fish and Wildlife Service as endangered or threatened, and none are currently on the list of critically rare plants (G1 and G2 status) developed by the Alaska Rare Plant Working Group (Lipkin and Murray 1997). However, 22 taxa are considered somewhat rare and are being tracked by the Alaska Natural Heritage Program's Biological and Conservation Database (BCD) (Table 2). The endemic Synthyris borealis Pennell (kittentails), found at all high alpine sites on Fort Greely, was formerly tracked in the BCD but is no longer on the Heritage Program list. The others are listed in Table 2 and are briefly described below with Heritage Program global (G) and state (S) ranks given for each tracked taxon. These ranks are based on a scale from 1 (critically imperiled because of extreme rarity) to 5 (demonstrably secure) with 2 (imperiled), 3 (rare or uncommon), and 4 (apparently secure). The ranks are further modified to denote subspecies or varieties (T) and uncertainty about taxonomic status (Q) (AKNHP 1998). All those described have state abundance levels of S3, S2, or S1 or a combination of two of these. Many of these tracked taxa are within their ranges and were not unexpected finds, but several are very significant additions to the body of knowledge about the Interior Alaska flora, and in some cases, the flora of Alaska. In the list below, the site number is given (Fig. 6, Table 1) where a species was found only once or twice. Where a species was found repeatedly, no site numbers are given.

1. Artemisia laciniata Willd. (cut-leaf sagewort) G5 
Table 2. Species on Alaska Natural Heritage Program Biological Conservation Database found on Fort Greely, with ranking.

\begin{tabular}{lll} 
Scientific name & Global rank* & State rankt \\
\hline Artemisia laciniata Willd. & $\mathrm{G} 5$ & $\mathrm{~S} 2$ \\
Carex atratiformis Britton ssp. raymondii (Calder) A. Pors. & $\mathrm{G} 5 \mathrm{~T} 5$ & $\mathrm{~S} 2$ \\
Carex crawfordii Fern. & $\mathrm{G} 5$ & $\mathrm{~S} 2 \mathrm{~S} 3^{* *}$ \\
Carex deweyana Schwein. & $\mathrm{G} 5$ & $\mathrm{~S} 1 \mathrm{SE} \dagger$ \\
Carex eburnea Boott & $\mathrm{G} 5$ & $\mathrm{~S} 2 \mathrm{~S} 3$ \\
Carex sychnocephala Carey & $\mathrm{G} 4$ & $\mathrm{~S} 1$ \\
Cryptogramma stelleri (Gmel.) Prantl & $\mathrm{G} 5$ & $\mathrm{~S} 2 \mathrm{~S} 3$ \\
Cystopteris montana (Lam.) Bernh. ex Desv & $\mathrm{G} 5$ & $\mathrm{~S} 3$ \\
Dodecatheon pulchellum (Raf.) Merr. & $\mathrm{G} 5 T 5 \mathrm{Q}$ & $\mathrm{S} 2$ \\
ssp. pauciflorum (Greene) Hulten & & \\
Draba incerta Payson & $\mathrm{G} 5$ & $\mathrm{~S} 2 \mathrm{~S} 3$ \\
Draba stenopetala Trautv. & $\mathrm{G} 3$ & $\mathrm{~S} 3$ \\
Festuca brevissima Yurtsev & $\mathrm{G} 3$ & $\mathrm{~S} 3$ \\
Glyceria pulchella (Nash) K. Schum. & $\mathrm{G} 5$ & $\mathrm{~S} 2 \mathrm{~S} 3$ \\
Phlox hoodii Richards. & $\mathrm{G} 5$ & $\mathrm{~S} 1 \mathrm{~S} 2$ \\
Phlox sibirica L. Ssp. richardsonii (Hook.) Hulten & $\mathrm{G} 4 \mathrm{~T} 2 \mathrm{~T} 3 \mathrm{Q}$ & $\mathrm{S} 2$ \\
Potamogeton obtusifolius Mertens and Koch & $\mathrm{G} 5$ & $\mathrm{~S} 1$ \\
Salix setchelliana Ball & $\mathrm{G} 3 \mathrm{G} 4$ & $\mathrm{~S} 3$ \\
Saxifraga adscendens L. ssp. oregonensis (Raf.) Bacig. & $\mathrm{G} 5 T 4 T 5$ & $\mathrm{~S} 2 \mathrm{~S} 3$ \\
Sisyrinchium montanum Greene & $\mathrm{G} 5$ & $\mathrm{~S} 1$ \\
Stellaria alaskana Hulten & $\mathrm{G} 3$ & $\mathrm{~S} 3$ \\
Viola selkirkii Pursh ex Goldie & $\mathrm{G} 5 ?$ & $\mathrm{~S} 3$
\end{tabular}

${ }^{*} \mathrm{G} 3$, very rare and local; G4, apparently secure globally; G5, secure globally; $T$ = global rank of subspecies or variey; $\mathrm{Q}=$ uncertain taxonomy.

†S1, critically imperiled in state; S2 imperiled in state; $\mathrm{S} 3$, rare or uncommon in state; SE, possibly introduced.

**Two different ranks in global or state (S2S3) indicates that rank is intermediate between the two. †† Possibly introduced to state.

S2: An Asian species with a very restricted range in North America, found on dry bluffs and open woods. It was found at Mark Lake (site 34).

2. Carex atratiformis Britton ssp. raymondii (Calder) A. Pors. (Raymond's sedge) G5T5 S2: A robust sedge of moist open areas. It was found at several sites in the Jarvis Creek Lowlands.

3. Carex crawfordii Fern. (Crawford's sedge) G5 S2S3: A sedge of dry sites and roadsides. It is proving to be more common than previously known and was observed at several sites in the Jarvis Creek Lowlands.

4. Carex deweyana Schwein. (Dewey sedge) G5 S1SE: Known from only a few sites in the state. A small, weak specimen with few perigynia was collected from a disturbed roadside at site 5. This sedge is suspected of being introduced to Alaska (SE); the habitat of this specimen would support this possibility.

5. Carex eburnea Boott (bristleleaf sedge) G5 S2S3: A small sedge characteristic of sandy gravel bar margins. It was found at several sites along the Delta River and Jarvis Creek.

6. Carex sychnocephala Carey (many headed sedge)
G4 S1: A very distinctive sedge, rarely seen in the state. Small, robust plants were found growing with other sedges and rushes along the wet meadow margin along the south end of Mark Lake (site 34).

7. Cryptogramma stelleri (Gmel.) Prantl (fragile rockbrake) G5 S2S3: A species of parsley fern. It was found at site 4 , where several clumps were growing on the moist fine sand of an old embankment, in the shade of tall alder scrub.

8. Cystopteris montana (Lam.) Bernh. ex Desv (mountain bladder fern) G5 S3: A calciphile. It was collected at site 1 , growing in fine moist sand in the shade of thick tall alder scrub, on a southwest facing slope above the river bar. It was also observed in the thick feathermoss of a white spruce forest at site 30 .

9. Dodecatheon pulchellum (Raf.) Merr. ssp. pauciflorum (Greene) Hulten (few-flowered shooting star) G5T5Q S2: A robust shooting star of dry interior sites. It was found at site 59, a south-west facing slope.

10. Draba incerta (Yellowstone whitlowgrass) Payson G5 S2S3: A small mustard. It was found on rock outcrops and gravelly breaks in the tundra along 
the northern flanks of Donnelly Dome (site 15).

11. Draba stenopetala Trautv. (thin petal whitlowgrass) G3 S3: A tightly compact whitlowgrass. Described as "rare and remarkable" by Hulten (1968), it is now known to be not quite so rare, but it is uncommon and still remarkable. It was found on a high ridge crest on Molybdenum Ridge (site 22).

12. Festuca brevissima Yurtsev G3 S3: A small alpine fescue, described by Hulten (1968) under the name Festuca ovina L. ssp. alaskensis Holmen. It was found at Donnelly Dome (site 15) and Molybdenum Ridge (site 53).

13. Glyceria pulchella (Nash) K. Schum. G5 S2S3: A small manna grass. It was found at site 11, southeast of Canister Lake.

14. Phlox hoodii Richards. (spiny phlox) G5 S1S2: A dwarf phlox known mostly from further north in Alaska and from central Yukon Territory. It was found by ABR biologists growing on a steep, south-facing bluff on Buffalo Hill (site 109), in a sagebrush-grass community.

15. Phlox sibirica L. ssp. richardsonii (Hook.) Hulten (Richardson's phlox) G4T2T3Q S2: A dwarf phlox, now known from several sites in the Alaska Range, but still quite rare. It was found growing in gravelly open soil and among rock outcrops along the ridge crest at the north end of Donnelly Dome (site 15), and is not very common there.

16. Potamogeton obtusifolius Mertens and Koch G5 S1: A distinctive but probably much overlooked pondweed. It was not recorded in Hulten (1968) and only one record was shown in Cody (1996). There are only two other Alaska records (both recent) for this plant at ALA: one from Palmer and one from Fort Yukon. It was found in shallow water at Mark Lake (site 34).

17. Salix setchelliana Ball (Setchell willow) G3G4 S3: A small, distinctive endemic. It was found on most of the gravel bar sites of the Delta River and at the mouth of Jarvis Creek.

18. Saxifraga adscendens L. ssp. oregonensis (Raf.) Bacig. G5T4T5 S2S3: A small, uncommon alpine species. Several plants without flowering stalks were found on the terminus of the Trident Glacier (site 57).

19. Sisyrinchium montanum Greene (mountain blueeyed grass) G5 SP: A small, densely tufted blue-eyed grass. Apparently, it is new to Alaska, except for an unpublished collection from the southeastern portion of the state.* The nearest record in Hulten (1968) is approximately $400 \mathrm{~km}$ away in the Yukon Territory, and

*Personal communication with A. Batten, A. Cholewa, and C. Parker, ALA, University of Alaska, Fairbanks, 1998. the specimen at ALA is from Dall Island, at the southern end of southeast Alaska. It was found in the moist, gravelly soil of the northeast corner of Buffalo Drop Zone (site 26), an abandoned creek bed now kept clear of brush and used for training maneuvers. Several dozen clumps of plants were observed. Also reported from site 101, east of Buffalo Drop Zone, by the LCTA crew.

20. Stellaria alaskana Hulten (Alaska starwort) G3 S3: A distinctive, large-flowered starwort, endemic to the region. It was found on gravelly screes, at many sites on Molybdenum Ridge.

21. Viola selkirkii Pursh ex Goldie (Selkirk violet) G5? S3: A small and easily overlooked violet. It was found at the same site and general habitat as Cryptogramma stelleri; it is known from a few widely spaced locations within Alaska.

22. While not especially rare, specimens of Primula eximia collected on Molybdenum Ridge were notable for their large size-some scapes were approximately $40 \mathrm{~cm}$ tall.

With the exception of Draba stenopetala, Festuca brevissima, Salix setchelliana, and Stellaria alaskana, which are endemic to the region, these taxa are peripheral species, with larger populations centered further south in North America, or west in Asia. Some of them barely reach Alaska, and are known from only a few sites in the state or nearby Canada (State Rank 1 or 2).

\section{Vascular plant range extensions}

A number of plants found during this survey are significant range extensions. Besides the tracked species Carex deweyana, Carex sychnocephala, Draba incerta, Festuca brevissima, Potamogeton obtusifolius, Phlox hoodii, Phlox sibirica ssp. richardsonii, Sisyrinchium montanum, and Viola selkirkii described above, several other more common plants were found more than $100 \mathrm{~km}$ (60 miles) beyond the ranges given in Hulten (1968):

1. Artemisia globularia Cham. ex Bess. (purple wormwood): A Beringian plant found mostly in the western part of the state. One other recent record exists for the Mount Hayes area. It was found at sites 17 and 53 on Molybdenum Ridge.

2. Calypso bulbosa (L.) Oakes (fairy slipper): A briefly flowering orchid known from farther south and farther north in the Fairbanks area. It is currently known from a number of new locations. It was found in a thick white spruce forest that had little understory growth (site 8).

3. Cypripedium guttatum Sw. var. guttatum Sw. (spotted lady's slipper): A large lady slipper with a range similar to calypso. This orchid, also known from many new sites, was fairly commonly on dry slopes at sites 13 and 29. 
4. Draba lonchocarpa Rydb. var. lonchocarpa: This species of whitlowgrass is known more typically from locations south of the Alaska Range. It was found on rocky outcrops at Donnelly Dome.

5. Eriophorum russeolum Fries ex Hartman (rusty cottongrass): Though Hulten records a limited interior distribution for this species, it is known from an increasing number of sites. It was also found during the Fort Wainwright inventory (Racine et al. 1997). It was collected by ABR biologists at site 117 near Gnat Lake, and also observed along the trail leading to site 12 (Granite Creek area).

6. Galium brandegei Gray: A small and easily overlooked bedstraw. It was found at the gravelly margin of Mark Lake (site 34). Its nearest location in Hulten (1968) is Fairbanks, and it was found at Fort Wainwright in the Yukon Maneuver Area (Racine et al. 1997).

7. Poa secunda J. Presl sensu Cody 1996: Includes P. nevadensis Vasey, P. ampla Merrill, $P$. stenantha, in part, . scabrella (Thurb.) Benth. and $P$. canbyi (Scribn.) Howell, most of which have restricted ranges in Alaska. A group in need of more work in Alaska, it was found in a young white spruce forest, near where it opened into tall willow scrub, at site 8 .

8. Potentilla virgulata A. Nels.: A cinquefoil that was also found during the Fort Wainwright survey. This collection represents another record that reduces the gap between its northern and southern Alaskan ranges.

9. Polygonum pennsylvanicum L. ssp. oneillii (Brenckle) Hulten: A small smartweed. It was mostly known from south of the Alaska Range and the Fairbanks area, and was found consistently in the muddy margin of ponds and lakes.

10. Primula cf. egaliksensis Wormsk. ex Hornem.(Greenland primrose): Small rosettes of nonfarinose leaves, without flower stalks. It was found in wet sand on silty stream banks at sites 38 and 58 on the Delta River and appears to fit the description of this small primrose. If so, it represent a sizable range extension.

11. Salix rotundifolia Trautv. ssp. dodgeana (Rydb.) Argus: Although Hulten (1968) shows only two stations in the Northwest Territories for what he called Salix dodgeana Rydb., Argus (1973) recognizes it as a subspecies of Salix rotundifolia and notes that it occurs sporadically throughout the range of ssp. rotundifolia. It was found in sandy scree on Molybdenum Ridge.

12. In addition, the alien species Achillea millefolium (sensu Hulten), Avena sativa, Gnaphalium uliginosum, Rumex longifolius, Rumex maritimus ssp. fueginus, and Rumex maritimus ssp. maritimus were large range extensions.

\section{Comparisons with other areas}

The number of vascular plant species documented here for Fort Greely (497) is very similar to the 491 species described for Fort Wainwright (Racine et al. 1997). However, only about $65 \%$ of the species ( 325) on Fort Greely also occur on Fort Wainwright. The remaining $35 \%$ of the species ( 170) found on Fort Greely do not occur on Fort Wainwright (marked with asterisk in Appendix A). At least two elements of the Fort Greely flora account for these differences:

- Strictly alpine species found in the mountain sites of the Alaska Range on Fort Greely. The southern portion of Fort Greely encompasses mountains of the Alaska Range (mainly Donelly Dome and Moybdemum Ridge), some of which reach elevations of $1800 \mathrm{~m}$ (nearly $6000 \mathrm{ft}$ ). These mountains support a wide variety of alpine communities that are missing from the treeless alpine hilltops of the Yukon Maneuver Area at Fort Wainwright, whose highest elevations are under $1000 \mathrm{~m}(3300 \mathrm{ft})$. On Fort Wainwright there are no scree slopes and fell fields, steep rock outcrops and snowmelt communities, common at Fort Greely alpine sites. A large number of species are typical of Fort Greely alpine sites, but absent from Fort Wainwright, and include Silene acaulis, Thalictrum alpinum, Primula eximia, Draba sp., Astragalus sp., Dryas sp., Papaver sp., Saxifraga sp. (10 species), and Lloydia serotina.

- Floodplain species that occur on the well-developed floodplains of the Delta River, Delta Creek, and Little Delta River. Only a small portion of the Tanana River floodplain occurs on Fort Wainwright. Species in this group include Minuartia dawsonensis, Salix setchelliana, and S. polaris.

About 150 species occur on Fort Wainwright but not on Fort Greely. These include several elements from habitats common on Fort Wainwright but absent on Fort Greely:

- Aquatic and wetland habitats. These habitats are well developed in the Tanana Flats and Chena River Lowlands on Fort Wainwright. Here, extensive rich fens and bogs occur as a result of groundwater discharge and thermokarst (Racine and Walters 1994). Species in this group belong to emergent and aquatic families such as the Alismataceae, Typhaceae, Urticaceae, Lemnacea, Araceae, and Balsaminaceae. Species include Alisma trivale, Lysmachia thyrsiflora, Juncus stygius, Sium sauve, Bidens cernua, Urtica dioica, Carex leptalea, and Carex lasiocarpa, all found at Fort Wainwright, but not found at Fort Greely.

- Disturbed and modified habitats. Many genera and 
species of alien plants were also missing from the flora on Fort Greely in part because of the exclusion of the cantonment area on Fort Greely from the study, which, for example, excluded the observed species Crepis tectorum and Potentilla gracilis. However, casual observation of the Greely cantonment revealed far fewer alien species than were found at either Fort Richardson or Fort Wainwright.

- Xeric-steppe habitats. Although there are dry, southfacing slopes on Fort Greely, these are much younger because of glaciation than the very old unglaciated dry slopes and bluffs, such as the Wood River Buttes on Fort Wainwright. Therefore, only a few sites at Fort Greely contained steppe-like elements such as Artemisia laciniata. Steppe species on Fort Wainwright not found on Fort Greely include Rosa woodsii.

\section{CONCLUSIONS}

The floristic inventory of Fort Greely produced a fairly comprehensive species list, typical for interior Alaska, but which also includes a significant number of alpine and floodplain species not found on Fort Wainwright. While the flora of the two bases together contains over 650 species and represent a significant proportion of the species of interior Alaska, there are important floristic differences between the two bases, reflecting strong environmental and landscape differences related to geological history, location relative to the Alaska Range, elevation, and permafrost.

Species found on Fort Greely with the largest range extensions include Sisyrinchium montanum, found at Buffalo Drop Zone and known from only one other site in Alaska, and Potamogeton obtusifolius, an aquatic species collected from Mark Lake, which is known from only two other locations in the state. Of the other plants collected during this survey, 20 are regarded as rare and tracked by the Alaska Natural Heritage Program.

In addition there are several significant habitats that are species-rich or unique where many of the rare plants were found. Molybdenum Ridge, Donnelly Dome, Buffalo Drop Zone, and Mark Lake account for most of the rare species occurrences. Other habitats that deserve special attention are xeric slopes containing low shrub and grassland communities, such as Artemesia frigida and Calamagrostis purpurascens, and high alpine ridges containing Dryas-dwarf Salix communities, scree slopes, and fell fields. Sites not well understood, which merit closer attention, include the dry morainal slopes where "krumholz" aspen communities occur, large bluffs of the west side of the Delta River (located within the impact area), and the Hayes Highland plateaus.
In terms of protection for Alaska's plant species biodiversity, we did not find any species on Fort Greely with Global G1 (critically imperiled globally) or G2 (imperiled globally) status in the Biological Conservation Database of the Alaska Natural Heritage Program. However, there are about 16 species with State S1 (critically imperiled in state) or S2 (imperiled in state) status. Land managers should be concerned about their conservation because land use on military installations is basically unrestricted (Duffy et al. 1999). Both the Buffalo Drop Zone and Mark Lake sites are heavily used for either training maneuvers or recreation, and though neither of the rare species at these sites appears to be adversely impacted, land managers should be aware of their significance.

\section{LITERATURE CITED}

Aiken, S.G., and S.J. Darbyshire (1990) Fescue grasses of Canada. Agriculture Canada Research Branch, publication 1844/E.

Aiken, S.G., M.J. Dallwitz, C.L. McJannet, and L.L. Consaul (1996) Festuca of North America: Descriptions, illustrations, identification, and information retrieval (http://biodiversity.uno.edu/delta/), 2 April 1998. Alaska Natural Heritage Program (1998) AKNHP vascular plant tracking list. (http://www.uaa.alaska.edu/ enri/aknhp_web/index.html), February 1998.

Argus, G. (1973) The genus Salix in Alaska and the Yukon. Publications in Botany, No. 2, National Museums of Canada, Ottawa, Ontario.

Brayshaw, T.C. (1985) Pondweeds and bur-reeds and their relatives: Aquatic families of monocotyledons in British Columbia. Occasional Paper No. 26 of the British Columbia Provincial Museum, Victoria, British Columbia, Canada.

Batten, A.R. (1997) Taxa documented by specimens for Mt. Hayes and Big Delta Quads. Northern Plant Documentation Center, Miscellaneous Report. Herbarium, University of Alaska Museum, Fairbanks, Alaska. Benson, C.S. (1972) Physical properties of the snow cover in the Fort Greely area, Alaska. U.S. Army Cold Regions Research and Engineering Laboratory, Special Report 178.

Church, R.E., T.L. Péwé, and M.J. Andresen (1965) Origin and environmental significance of large-scale patterned ground, Donnelly Dome area, Alaska. U.S. Army Cold Regions Research and Engineering Laboratory, Research Report 159.

Cody, W.J. (1996) Flora of the Yukon Territory. Ottawa, Ontario: NRC Research Press.

Duffy, D.C., K. Boggs, R.H. Hagenstein, R.Lipkin, and J.A. Michaelson (1999) Landscape assessment of 
the degree of protection of Alaska's biodiversity. Conservation Biology, 13: 1332-1345.

Flora of North America Editorial Committee (1993) Flora of North America North of Mexico. New York: Oxford University Press.

Hitchcock, C.L., A. Cronquist, M. Owenby, and J.W. Thompson (1955-1969) Vascular Plants of the Pacific Northwest, Parts 1-5. Seattle: University of Washington Press.

Holmes, G.W. and W.S. Benninghoff (1957) Terrain study of the army test area, Fort Greely, Alaska. U.S. Geological Survey Military Geology Branch Washington, D.C.

Hulten, E. (1968) Flora of Alaska and Neighboring Territories. Stanford, California: Stanford University Press.

Hulten, E. (1973) Supplement to the Flora of Alaska and Neighboring Territories. A study in the flora of Alaska and the Transberingian connection. Botaniska Notiser, 126: 459-512.

Jorgenson, M.T., J. E. Roth, M.D. Smith, S.F. Schlentner, W. Lentz, E.R. Pullman, and C.H. Racine (2001) An ecological land survey for Fort Greely, Alaska. U.S. Army Engineer Research and Development Center, Cold Regions Research and Engineering Laboratory, Technical Report TR-01-4.

Kartesz, J.T. (1994) A synonymized checklist of the Vascular Flora of the United States, Canada and Greenland. Oregon: Timber Press.

Lichvar, R., C. Racine, B. Murray, G. Tande, R. Lipkin, and M. Duffy (1997) A floristic inventory of vascular and cryptogam plant species at Fort Richardson, Alaska. U.S. Army Waterways Experiment Station, Environmental Laboratory, Technical Report EL-97-4.

Lichvar, R., and S. Sprecher (1999) Wetland delineation for Fort Greely, Ak. Final Report to U.S. Army Alaska, Fort Richardson, Alaska.

Lipkin, R., and D.F. Murray (1997) Alaska rare plant field guide. U.S. Fish and Wildlife Service, National Park Service, Bureau of Land Management,
Alaska Natural Heritage Program, and U.S. Forest Service.

Murray, D.M., C. Parker, and A.R. Batten (1994) Flora of Alaska (preliminary). Northern Plant Documentation Center Report 86. Herbarium, University of Alaska Museum, Fairbanks, Alaska.

Nelson, G.L. (1995) Overview of environmental and hydrogeologic conditions near Big Delta, Alaska. U.S. Geological Survey Open-File Report 95-180.

Péwé, T.L., and R.D. Reger (1983) Guidebook to permafrost and quaternary geology along the Richardson and Glenn Highways between Fairbanks and Anchorage, Alaska. Guidebook 1. In Fourth International Conference on Permafrost, 18-22 July, Fairbanks, Alaska. Alaska Division of Geology and Geophysical Surveys, Anchorage, Alaska.

Porsild A.E. (1974) Materials for a flora of central Yukon Territory. Publications in Botany, No. 4, National Museums of Canada, Ottawa, Ontario.

Racine, C.H., and J.C. Walters (1994) Groundwaterdischarge wetlands in the Tanana Flats, interior Alaska, USA. Arctic and Alpine Research, 26: 418-426.

Racine, C., R. Lichvar, B. Murray, G. Tande, R. Lipkin, and M. Duffy (1997) A floristic inventory and spatial database for Fort Wainwright, interior Alaska. U.S. Army Cold Regions Research and Engineering Laboratory, Special Report 97-23.

U.S. Soil Conservation Service (1994) Plants of Alaska, alphabetical listing. Report 5, U.S. Department of Agriculture, Anchorage, Alaska

Viereck, L.A., and E.L. Little, Jr. (1972) Alaska trees and shrubs. Agriculture Handbook No. 410. U.S. Forest Service, Washington, DC.

Welsh, S.L. (1974) Anderson's Flora of Alaska and Adjacent Parts of Canada. Provo, Utah: Brigham Young University Press.

Williams, C.L., and R. Lipkin (1991) Rare plants of the Steese National Conservation Area and White Mountain National Recreation Area. Unpublished report, Alaska Natural Heritage Program, Anchorage, Alaska. 


\section{APPENDIX A: CHECKLIST OF COLLECTED VASCULAR PLANTS FROM FORT GREELY MILITARY INSTALLATION, ALASKA, ARRANGED ALPHABETICALLY}

Nomenclature of this checklist follows the University of Alaska Museum Plants Database (ALABASE). Recent revisions have resulted in some name changes. If the plant name given here is different from that used in Hulten (1968), its synonym is presented in brackets; * in front of plant name indicates that the taxon was not collected on Fort Wainwright.

Achillea borealis Bong.

Achillea millefolium L. sensu Hulten

Achillea sibirica Ledeb.

*Acomastylis rossii (R. Br.) E. Greene [= Geum rossii (R. Br.) Ser.]

Aconitum delphinifolium DC. ssp. delphinifolium

Actaea rubra (Ait.) Willd.

Adoxa moschatellina $\mathrm{L}$.

Agrostis scabra Willd.

* Allium schoenoprasum L.

* Alnus sinuata (Regel) Rydb. [= Alnus crispa (Ait.) Pursh ssp. sinuata (Regel) Hulten] Alnus tenuifolia Nutt. [= Alnus incana (L.) Moench ssp. tenuifolia (Nutt.) Breitung]

Alnus viridis Vill. ssp. crispa (Ait.) A. Love \& D. Love [= Alnus crispa (Ait.) Pursh ssp. crispa]

Alopecurus aequalis Sobol.

Andromeda polifolia $\mathrm{L}$.

* Androsace chamaejasme Wulfen ssp. lehmanniana (Spreng.) Hulten

Androsace septentrionalis L.

* Anemone drummondii S. Wats.

Anemone narcissiflora L. ssp. interior Hulten

Anemone parviflora Michx.

Anemone richardsonii Hook.

* Angelica lucida $\mathrm{L}$.

Antennaria friesiana (Trautv.) Ekman

* Antennaria monocephala DC. ssp. monocephala

* Antennaria monocephala DC. ssp. philonipha (A. Porsild) Hulten

Aquilegia brevistyla Hook.

Arabis hirsuta (L.) Scop. ssp. pycnocarpa (M. Hopk.) Hulten

Arabis lyrata L. ssp. kamchatica (Fisch.) Hulten

Arctagrostis latifolia (R. Br.) Griseb. ssp. arundinacea (Trin.) Tzvelev

* Arctagrostis latifolia (R. Br.) Griseb. ssp. latifolia (R. Br.) Griseb.

Arctophila fulva (Trin.) Rupr. ex Anderss.

Arctostaphylos uva-ursi (L.) Spreng. var uva-ursi

Arctous alpina (L.) Niedenzu [= Arctostaphylos alpina (L.) Spreng.]

Arctous rubra [= Arctostaphylos rubra (Rehd. \& Wilson) Fern.]

* Arenaria capillaris Poir.

Arnica angustifolia M. Vahl [= Arnica alpina (L.) Olin ssp. angustifolia (M. Vahl) Maguire]

Arnica griscomii Fern. ssp. frigida (C.A. Mey. ex Iljin) S. J. Wolf [= Arnica frigida C.A.

Mey. ex Iljin]

*Arnica lessingii (Torr. \& Gray) Greene

Artemisia alaskana Rydb.

Artemisia arctica Less.

* Artemisia borealis Pallas

Artemisia frigida Willd.

* Artemisia globularia Cham. ex Bess.

Artemisia laciniata Willd. 
Artemisia tilesii Ledeb. ssp. elatior (Torr. \& Gray) Hulten

Aster sibiricus L.

Astragalus adsurgens Pallas ssp. viciifolius (Hulten) Welsh

Astragalus alpinus L.

* Astragalus americanus (Hook.) M.E. Jones

Astragalus bodinii Sheldon

* Astragalus eucosmus Robins. ssp. eucosmus

* Astragalus umbellatus Bunge

* Astragalus williamsii Rydb.

* Avena sativa L.

Barbarea orthoceras Ledeb.

Beckmannia erucaeformis (L.) Host ssp. baicalensis (Kuzn.) Hulten

* Betula glandulosa Michx.

Betula hybrid

Betula nana L.

* Betula neoalaskana Sarg. [= Betula papyrifera Marsh. ssp. humilis (Regel) Hulten]

Betula papyrifera Marsh.

Bistorta plumosa (Small) E. Greene [= Polygonum bistorta L. ssp. plumosum (Small)

Hulten]

Bistorta vivipara (L.) Gray [= Polygonum viviparum L.]

Boschniakia rossica (Cham. \& Schlecht.) Fedtsch.

Botrychium lunaria (L.) Sw.

* Boykinia richardsonii (Hook.) Rothrock

Bromopsis inermis (Leyss.) Holub [= Bromus inermis Leyss.]

Bromopsis pumpelliana (Scribn.) Holub ssp. pumpellianus [= Bromus pumpellianus Scribn. var. pumpellianus]

* Bupleurum triradiatum Adams ssp. arcticum (Regel) Hulten

Calamagrostis canadensis (Michx.) Beauv.

Calamagrostis canadensis (Michx.) Beauv. ssp. canadensis

Calamagrostis inexpansa Gray

Calamagrostis purpurascens $\mathrm{R}$. Br.

* Callitriche hermaphroditica L.

Callitriche verna L. emend. Kutz.

Calypso bulbosa (L.) Oakes

Campanula lasiocarpa Cham. ssp. lasiocarpa

Campanula uniflora L.

* Cardamine bellidifolia L.

* Cardamine purpurea Cham. \& Schlecht.

* Cardamine umbellata E. Greene

Carex aenea Fern.

Carex aquatilis Wahlenb.

* Carex aquatilis Wahlenb. ssp. Aquatilis

* Carex arcta Boott

Carex atherodes Spreng.

* Carex atratiformis Britt. ssp. raymondii (Calder) Pors. [= Carex raymondii Calder]

* Carex aura Nutt.

* Carex bicolor Bellardi ex All.

Carex bigelowii Torr. ex Schwein.

Carex canescens L.

Carex capillaris L.

Carex capitata $\mathrm{L}$.

Carex concinna $\mathrm{R}$. Br. 
Carex crawfordii Fern.

* Carex cf. deweyana Schwein.

Carex diandra Schrank

Carex disperma Dew.

* Carex eburnea Boott

Carex filifolia Nutt.

Carex garberi Fern. ssp. bifaria (Fern.) Hulten

* Carex gynocrates Wormsk. ex Drej. [= Carex dioica L. ssp. gynocrates (Wormsk.) Hulten]

* Carex kelloggii W. Boott

Carex krausei Boeckl.

* Carex lachenalii Schkuhr.

Carex limosa L.

* Carex livida (Wahlenb.) Willd.

* Carex lugens Holm

* Carex macloviana d'Urv. [= Carex macloviana d'Urv. ssp. pachystachya (Cham.) Hulten]

Carex magellanica Lam. ssp. irrigua (Wahlenb.) Hulten

Carex media R. Br.

* Carex membranacea Hook.

* Carex microchaeta Holm

Carex microchaeta Holm ssp. microchaeta

Carex microchaeta Holm ssp. nesophila (Holm) D. Murray

* Carex microglochin Wahlenb.

Carex oederi Retz. ssp. viridula (Michx.) Hulten

* Carex petricosa Dewey

Carex podocarpa $\mathrm{R}$. Br.

Carex rostrata Stokes

Carex rotundata Wahlenb.

Carex cf. rotundata Wahlenb.

Carex rupestris All.

Carex saxatilis L. ssp. laxa (Trautv.) Kalela

* Carex scirpoidea Michx.

Carex supina Willd. ex Wahlenb. var. spaniocarpa (Steud.) Boivin

Carex sychnocephala Carey

Carex tenuiflora Wahlenb.

Carex utriculata Boott [= Carex rhynchophysa C. A. Meyer]

Carex vaginata Tausch

* Carex williamsii Britt.

Cassiope tetragona (L.) D. Don ssp. tetragona

Castilleja caudata (Pennell) Rebr.

* Castilleja yukonis Pennell

* Cerastium beeringianum Cham. \& Schlecht.

* Cerastium beeringianum Cham. \& Schlecht. var. beeringianum

* Cerastium fontanum Baumg.

Chamaedaphne calyculata (L.) Moench

Chenopodium album $\mathrm{L}$.

Chenopodium capitatum (L.) Aschers.

Chrysosplenium tetrandrum (Lund) Th. Fries

* Chrysosplenium wrightii Franch. \& Savigny

* Claytonia sarmentosa C.A. Mey.

* Claytonia tuberosa Pallas ex J.A. Schultes

Cnidium cnidiifolium (Turcz.) Schischk.

Comarum palustre L. [= Potentilla palustris (L.) Scop.]

Corallorrhiza trifida Chatelain

Cornus canadensis L. 
Corydalis sempervirens (L.) Pers.

Crepis elegans Hook.

* Crepis nana Richards.

Cryptogramma stelleri (Gmel.) Prantl

Cypripedium guttatum $\mathrm{Sw}$.

Cypripedium passerinum Richards.

Cystopteris fragilis (L.) Bernh.

* Cystopteris fragilis (L.) Bernh. ssp. dickieana (Sim) Hyl.

* Cystopteris montana (Lam.) Bernh. ex Desv.

Delphinium glaucum S. Wats.

Deschampsia cespitosa (L.) Beauv.

* Descurainia richardsonii (Sweet) O. Schulz

Descurainia sophioides (Fisch. ex Hook.) O.E. Schulz

Diapensia lapponica L. ssp. obovata (F.Schm.) Hulten

* Diphasiastrum alpinum (L.) Holub [= Lycopodium alpinum L.]

* Diphasiastrum complanatum (L.) Holub [= Lycopodium complanatum L.]

* Dodecatheon frigidum Cham. \& Schlecht.

Dodecatheon pulchellum (Raf.) Merr. ssp. pauciflorum (E. Greene) Hulten

* Draba alpina L. complex

* Draba cana Rydb. [= Draba lanceolata Royle]

Draba glabella Pursh var. glabella Pursh [= Draba hirta L.]

* Draba incerta Payson

* Draba lonchocarpa Rydb. var. lonchocarpa

* Draba longipes Raup

* Draba nivalis Lilj.

* Draba stenopetala Trautv.

Dracocephalum parviflorum Nutt.

Drosera rotundifolia L.

*Dryas alaskensis A. Porsild [= Dryas octopetala L. ssp. alaskensis (Porsild) Hulten]

Dryas drummondii Richards. ex Hook.

* Dryas integrifolia Vahl

* Dryas octopetala L.

Dryas octopetala L. ssp. octopetala var. octopetala

Dryopteris fragrans (L.) Schott

* Elaeagnus commutata Bernh. ex Rydb.

Eleocharis acicularis (L.) Roem. \& Schult

Eleocharis palustris (L.) Roem. \& Schult.

Elymus alaskanus (Scribn. \& Merr.) A. Love ssp. hyperarcticus (Polunin) A. Love \& D.

Love [= Agropyron boreale (Turcz.) Drobov ssp. hyparcticum (Polunin) Melderis]

Elymus cf. macrourus (Turcz.) Tzvelev [= Agropyron macrourum (Turcz. ) Drobov]

Elymus trachycaulus (Link) Gould ex Shinners cf. ssp. subsecundus (Link) Gould [= Agroupyron subsecundum (Link Hitchc.]

Elymus trachycaulus (Link) Gould ex Shinners ssp. trachycaulus [= Agropyron pauciflorum Schwein.) Hitchc.]

Elymus trachycaulus (Link) Gould ex Shinners ssp. violaceus (Hornem.) A. \& D. Love [= Agropyron violaceum (Hornem.) Lange]

Elytrigia repens (L.) Beauv. var. repens [= Agropyron repens (L.) Beauv.]

Empetrum hermaphroditum Lange ex Hagerup [= Empetrum nigrum L. ssp. hermaphroditum (Lange ex Hagerup ) Bocher]

Epilobium angustifolium $\mathrm{L}$.

Epilobium ciliatum Raf. ssp. adenocaulon (Haussk.) Hoch \& Raven [= Epilobium adenocaulon Haussk.] 
Epilobium hornemannii Rchb. ssp. hornemannii

Epilobium latifolium $\mathrm{L}$.

Epilobium palustre L.

Equisetum arvense $\mathrm{L}$.

Equisetum fluviatile L. ampl Ehrh.

Equisetum palustre $\mathrm{L}$.

Equisetum pratense Ehrh.

Equisetum scirpoides Michx.

Equisetum silvaticum L.

Equisetum variegatum Schleich. ex F. Weber \& D.M.H. Mohr

Erigeron acris L.

Erigeron caespitosus Nutt.

Erigeron elatus $\mathrm{E}$. Greene

* Erigeron eriocephalus J. Vahl

Erigeron glabellus Nutt. ssp. pubescens (Hook.) Cronq.

* Erigeron humilis Graham

Erigeron lonchophyllus Hook.

* Erigeron purpuratus Greene

Eriophorum angustifolium Honck. ssp. subarcticum (Vassiljev) Hulten

* Eriophorum brachyantherum Trautv. \& C.A. Mey.

Eriophorum gracile W.D.J. Koch

Eriophorum russeolum Fries

Eriophorum scheuchzeri Hoppe

* Eriophorum scheuchzeri Hoppe var. tenuifolium Ohwi

Eriophorum vaginatum $\mathrm{L}$.

* Eritrichium splendens Kearney

Erysimum cheiranthoides L.

Euphrasia disjuncta Fern. \& Wieg.

* Eutrema edwardsii R. Br.

Festuca altaica Trin.

Festuca brachyphylla J.A. Schultes ex J.A. \& J.H. Schultes

* Festuca brevissima Yurtsev [= Festuca ovina L. ssp. alaskensis Holmen]

* Festuca rubra L. sens lat.

*Festuca rubra L. ssp. richardsonii (R. Br.) Hulten [= Festuca rubra L., in part]

Festuca saximontana Rydb.

*Festuca vivipara $(\mathrm{L}$.) Smith [= "Festuca vivipara"]

Fragaria virginiana Duchesne ssp. glauca (S. Wats.) Staudt

Galium boreale L.

Galium brandegei A. Gray

Galium trifidum L. ssp. trifidum

Gastrolychnis affinis (J. Vahl) Tolm. \& Koznanch. [= Melandrium affine J. Vahl]

* Gastrolychnis apetala (L.) Tolm. \& Kozhanch. [= Melandrium apetalum (L.) Fenzl ssp. arcticum (E. Fries) Hulten]

Gastrolychnis ostenfeldii (A. Pors.) D. Murray [= Melandrium taimyrense Tolm.]

* Gentiana algida Pall.

Gentiana glauca Pallas

* Gentiana prostrata Haenke

Gentianella propinqua (Richards.) J. Gillett ssp. propinqua (Richards.) J. Gillett [= Gentiana propinqua Richards. ssp. propinqua]

Gentianopsis detonsa (Rottb.) Ma ssp. yukonensis (J. Gillett) J. Gillett [= Gentiana barbata

Froel.]

Geocaulon lividum (Richards.) Fern. 
Geum perincisum Rydb. [= Geum macrophyllum Willd. var. perincisum (Rydb.) Raup]

Glyceria borealis (Nash) Batchelder

Glyceria maxima (Hartm.) Holmb. ssp. grandis (S. Wats.) Hulten

Glyceria pulchella (Nash) K. Schum.

Gnaphalium uliginosum L.

Gymnocarpium dryopteris (L.) Newman

Goodyera repens (L.) R. Br. ex Ait. f.

Hedysarum alpinum $\mathrm{L}$.

* Hedysarum hedysaroides (L.) Schinz \& Thell.

Hedysarum mackenzii Richards.

Hierochloe alpina (Sw.) Roem. \& Schult.

Hierochloe odorata (L.) Beauv.

Hippuris vulgaris $\mathrm{L}$.

Hordeum jubatum L.

Huperzia selago (L.) Bernh. ex Mart. \& Schrank [= Lycopodium selago L. ssp. appressum

(Desv.) Hulten, Huperzia haleakalensis (Breck.) Holub in FNA (1993)]

Iris setosa Pallas ex Link var. interior E. Anders.

* Isoetes echinospora Durieu [=Isoetes muricata Dur. var braunii auct.]

Juncus alpinus Vill.

Juncus arcticus Willd. ssp. alaskanus Hulten

Juncus arcticus Willd. ssp. ater (Rydb.) Hulten

*Juncus biglumis L.

Juncus bufonius L.

Juncus castaneus Sm. ssp. castaneus

Juncus castaneus Sm. ssp. leucochlamys (Zing. ex Krecz.) Hulten

Juncus filiformis L.

Juncus triglumis L. ssp. albescens (Lange) Hulten

Juniperus communis L. ssp. nana (Willd.) Syme

* Kobresia myosuroides (Vill.) Fiori

* Lagotis glauca Gaertn.

Larix laricina (Du Roi) K. Koch

Ledum groenlandicum Oeder [= Ledum palustre L. ssp. groenlandicum (Oeder) Hulten]

Ledum palustre L. ssp. decumbens (Ait.) Hulten

Lepidium densiflorum Schrad.

* Lesquerella arctica (Wormsk. ex Hornem.) S. Wats.

Leymus innovatus (Beal) Pilger [= Elymus innovatus Beal]

*Linnaea borealis L. ssp. americanus (J. Forbes) Hulten

Linnaea borealis L. ssp. borealis $\mathrm{L}$.

Linum lewisii Pursh [= Linum perenne L. ssp. lewisii (Pursh) Hulten]

* Lloydia serotina (L.) Reichenb.

Loiseleuria procumbens (L.) Desv.

Lomatogonium rotatum (L.) Fries ex Fern.

Lupinus arcticus $\mathrm{S}$. Wats.

* Luzula arcuata (Wahlenb.) Sw. ssp. arcuata (Wahlenb.) Sw.

Luzula confusa Lindeberg

Luzula multiflora (Retz.) Lej. ssp. multiflora var. frigida (Buch.) Sam.

Luzula parviflora (Ehrh.) Desv.

Luzula rufescens Fisch. ex E. Mey.

* Luzula spicata (L.) DC. 
* Luzula tundricola Gorodk.

Lycopodium annotinum L. ssp. annotinum

Lycopodium annotinum L. ssp. pungens (LA Pyl.) Hult

* Lycopodium clavatum L. var. monostachyon Grev. \& Hook.

Matricaria matricarioides (Less.) Porter

Mertensia paniculata (Ait.) G. Don

Minuartia arctica (Stev. ex Ser.) Graebn.

* Minuartia dawsonensis (Britt.) House

* Minuartia macrocarpa (Pursh) Ostenf.

* Minuartia obtusiloba (Rydb.) House

* Minuartia rossii (R. Br.) Graebn.

* Minuartia rubella (Wahlenb.) Hiern

Moehringia lateriflora (L.) Fenzl

Moneses uniflora (L.) Gray

Myrica gale L.

Myriophyllum sibiricum Kom. [= Myriophyllum spicatum L.]

* Myosotis alpestris F. W. Schmidt ssp. asiatica Vestergr.

Nuphar polysepalum Engelm.

Orthilia secunda (L.) House [= Pyrola secunda L.]

Oxycoccus microcarpus Turcz.

* Oxyria digyna (L.) Hill

* Oxytropis bryophila (E. Greene) Yurtsev [= Oxytropis nigrescens (Pallas) Fisch. ex DC.

ssp. bryophila]

Oxytropis deflexa (Pallas) DC. var. foliolosa (Hook.) Barneby

Oxytropis deflexa (Pallas) DC. var. sericea Torr. \& Gray

* Oxytropis maydelliana Trautv.

Oxytropis varians (Rydb.) Schumann [= Oxytropis campestris (L.) DC. ssp. gracilis (Nels.)

Hulten]

* Oxytropis viscida Nutt.

* Papaver macounii Greene

* Papaver radicatum Rottb. ssp. radicatum [= Papaver lapponicum (Tolm.) Nordh. ssp. occidentale (Lundstr.) Knaben]

* Parnassia kotzebuei Cham. ex Spreng.

Parnassia palustris L. ssp. neogaea (Fern.) Hulten

Parrya nudicaulis ( L.) Boiss.

Pedicularis capitata M.F. Adams

Pedicularis labradorica Wirsing

Pedicularis lanata Cham. \& Schlecht. [= Pedicularis kanei Durand]

Pedicularis langsdorfii Fisch. ex Stev.

* Pedicularis sudetica Willd.

* Pedicularis verticillata $\mathrm{L}$.

Pentaphylloides floribunda (Pursh) A. Love [= Potentilla fruticosa L.]

Petasites frigidus (L .) Fries

Petasites sagittatus (Banks ex Pursh) Gray

Phleum pratense $\mathrm{L}$.

* Phlox hoodii Richards.

* Phlox sibirica L. ssp. richardsonii (Hook.) Hulten

Picea glauca (Moen ch) Voss

Picea mariana (P. M ill.) B.S.P.

Pinguicula villosa $\mathrm{L}$. 
* Pinguicula vulgaris L.

* Plantago canescens M.F. Adams

Plantago major L.

Platanthera hyperborea (L.) Lindl.

Platanthera obtusata (Banks ex Pursh) Lindl.

* Poa cf. alpigena (Fries) Lindman

Poa alpina L.

Poa aпnua L.

Poa $\operatorname{arctica} \mathrm{R}$. Br. sens lat.

Poa glauca M . Vahl

* Poa lanata Scribn. \& Merr.

* Poa paucispicula Scribn. \& Merr.

Poa pratensis L.

* Poa pseudoabbreviata Rosh.

* Poa secunda J. Presl [= includes Poa nevadensis Vasey, Poa ampla Merrill, Poa

stenantha, in part, Poa scabrella (Thurb.) Benth. and Poa canbyi (Scribn.) Howell]

Podistera macounii (Coult. \& Rose) Mathias \& Constance [= Ligusticum mutellinioides

(Crantz) Willar ssp. alpinum (Ledeb.) Thell.]

Polemonium acutiflorum Willd. ex Roemer \& J.A. Schultes

* Polemonium pulcherrimum Hook.

Polygonum alaskanum (Small) W. Wight

Polygonum amphibium L.

Polygonum aviculare L.

Polygonum pennsylvanicum L. ssp. oneillii (Brenckle) Hulten

Populus balsamifera L. ssp. balsamifera

Populus tremuloides Michx.

Potamogeton alpinus Balbis

Potamogeton filiformis Pers.

*Potamogeton foliosus Raf.

Potamogeton gramineus $\mathrm{L}$.

* Potamogeton obtusifolius Mertens \& Koch

Potamogeton praelongus Wulfen

Potamogeton pusillus L. [= Potamogeton berchtoldii Fieb.]

Potamogeton richardsonii (Benn.) Rydb. [= Potamogeton perfoliatus L. ssp.

richardsonii (Bennett) Hulten]

Potamogeton zosteriformis Fern. [= Potamogeton zosterifolius Schum. ssp.

zosteriformis (Fern.) Hulten]

* Potentilla anserina $\mathrm{L}$.

* Potentilla biflora Willd. ex Schlecht.

Potentilla hookeriana Lehm.

Potentilla multifida $\mathrm{L}$.

Potentilla norvegica L. ssp. monspeliensis (L.) Ashers. \& Graebn.

Potentilla pensylvanica L.

Potentilla uniflora Ledeb.

Potentilla virgulata A. Nels.

* Primula cf. egaliksensis Wormsk. ex Hornem.

* Primula eximia Greene [= Primula tschuktschorum Kjellm. var. arctica (Koidz.) Fern.]

Pulsatilla patens (L.) P. Mill. ssp. multifida (Pritz.) Zamels

Pyrola asarifolia Michx.

Pyrola chlorantha Sw.

Pyrola grandiflora Radius

* Pyrola minor L.

Ranunculus gmelini DC. ssp. gmelini 
Ranunculus hyperboreus Rottb.

Ranunculus lapponicus $\mathrm{L}$.

* Ranunculus nivalis $\mathrm{L}$.

Ranunculus reptans $\mathrm{L}$.

Ranunculus sceleratus L. ssp. multifidus (Nutt.) Hulten

Ranunculus trichophyllus Chaix

Rhinanthus minor L. ssp. borealis (Sterneck) Love

* Rhodiola integrifolia Raf. [= Sedum rosea (L.) Scop. ssp. integrifolium (Raf.) Hulten]

* Rhododendron lapponicum (L.) Wahlenb.

Ribes hudsonianum Richards.

Ribes triste Pallas

Rorippa barbareifolia (DC.) Kitigawa [= Rorippa hispida (Desv.) Britt. var.

barbareaefolia (DC.) Hulten]

Rorippa palustris (L.) Besser ssp. glabra (O. Schulz) Stuckey [= Rorippa islandica

(Oeder) Borb. ssp. fernaldiana (Butt. \& Abbe) Hulten]

Rosa acicularis Lindl.

Rubus arcticus L. ssp. arcticus L.

Rubus chamaemorus $\mathrm{L}$.

Rubus idaeus $\mathrm{L}$.

Rumex arcticus Trautv.

* Rumex longifolius DC.

* Rumex maritimus L. ssp. fueginus (L. Phillips) Hulten

* Rumex maritimus L. ssp. maritimus

* Sagina nivalis (Lindbl.) Fries [= Sagina intermedia Fenzl]

* Salix alaxensis (Anderss.) Coville var. alaxensis (Anderss.) Coville

Salix alaxensis (Anderss.) Coville var. longistylis (Rydb.) Schneid.

Salix arbusculoides Anderss.

Salix arctica Pall.

* Salix barclayi Anderss.

Salix bebbiana Sarg. [= Salix depressa L. ssp. rostrata (Anderss.) Hiitonen]

Salix brachycarpa Nutt. ssp. niphoclada (Rydb.) Argus

Salix fuscescens Anderss.

Salix glauca L.

Salix glauca L. var. acutifolia (Andersson) C. Schneider

* Salix lanata L. ssp. richardsonii (Hook.) A. Skvortsov

Salix myrtillifolia Anderss.

Salix novae-angliae Anderss. [= Salix myrtillifolia Anderss., in part]

Salix planifolia Pursh ssp. pulchra (Cham.) Argus

* Salix polaris Wahlenb. ssp. pseudopolaris (Flod.) Hulten

* Salix reticulata $\mathrm{L}$.

* Salix rotundifolia Trautv. ssp. dodgeana (Rydb.) Argus [= Salix dodgeana Rydb.]

* Salix setchelliana Ball

Sanguisorba officinalis L.

* Sanguisorba stipulata Raf.

Saussurea angustifolia (Willd.) DC. (including one specimen that fits Saussurea viscida

Hulten var. yukonensis (Pors.) sensu Hulten)

* Saxifraga cf. adscendens L. ssp . oregonensis (Raf.) Bacig.

* Saxifraga bronchialis L.

* Saxifraga calycina Stern b. [= Saxifraga davurica Willd. ssp. grandipetala (Engler \&

Irmsch) Hulten]

Saxifraga cernua L.

* Saxifraga eschscholtzii Sternb.

* Saxifraga flagellaris Willd. ex Sternb. 
* Saxifraga hieraciifolia Waldst. \& Kit

* Saxifraga hirculus L.

Saxifraga nelsoniana D. Don [= Saxifraga punctata L.]

* Saxifraga oppositifolia L.

Saxifraga reflexa Hook.

* Saxifraga rivularis L.

* Saxifraga serpyllifolia Pursh

* Saxifraga spicata D. Don

Saxifraga tricuspidata Rottb.

Scirpus validus M. Vahl

Selaginella sibirica (Milde) Hieron.

Senecio atropurpureus (Ledeb.) Fedtsch.

Senecio congestus (R. Br.) DC.

* Senecio kjellmannii [= Senecio atropurpureus (Ledeb.) Fedtsch. ssp. tomentosus

(Kjellm.) Hulten]

Senecio lugens Richards.

* Senecio ogotorukensis Packer [= Senecio conterminus Greenm.]

Senecio pauciflorus Pursh

* Senecio pauperculus Michx.

* Senecio resedifolius Less.

Senecio tundricola Tolm. [= Senecio fuscatus (Jord. \& Fourr.) Hayek]

* Senecio yukonensis Porsild

Shepherdia canadensis (L.) Nutt.

* Silene acaulis (L.) Jacq.

* Silene repens Patrin ex Pers.

Silene williamsii Britt. [= Silene menziesii Hook. ssp. williamsii (Britt.) Hulten]

* Sisyrinchium montanum Greene

Solidago decumbens Greene var. oreophila (Rydb.) Fern.

Solidago multiradiata Ait.

Sparganium angustifolium Michx.

Sparganium hyperboreum Laestad. ex Beurling

Sparganium minimum (Hartman F.) Fries

Spiraea stevenii (Schneid.) Rydb. [= Spiraea beauverdiana Schneid.]

Spiranthes romanzoffiana Cham.

* Stellaria alaskana Hulten

Stellaria borealis Bigelow

Stellaria calycantha (Ledeb.) Bong.

Stellaria crassifolia Ehrh.

* Stellaria edwardsii R. Br.

Stellaria laeta Richardson

Stellaria longifolia Muhl. ex Willd.

Stellaria longipes Goldie

* Subularia aquatica $\mathrm{L}$.

Synthyris borealis Pennell

* Taraxacum kamtschaticum Dahlst.

* Taraxacum lacerum E. Greene

Thalictrum alpinum $\mathrm{L}$.

Thalictrum sparsiflorum Turcz. ex Fisch. \& C.A. Mey.

Tofieldia coccinea Richards.

* Tofieldia pusilla (Michx.) Pers.

* Torularia humilis (C. Meyer) O. Schulz [= Braya humilis (C.A. Mey.) B.L. Robins.]

* Trichophorum caespitosum (L.) Hartman

Trientalis europaea L. ssp. arctica (Fisch. ex Hook.) Hulten 
Trifolium hybridum $\mathrm{L}$.

Triglochin palustre $\mathrm{L}$.

Trisetum spicatum (L.) Richter

Utricularia intermedia Hayne

Utricularia minor L.

Utricularia vulgaris L. ssp. macrorhiza (Le Conte) R.T. Clausen

Vaccinium uliginosum L.

Vaccinium vitis-idaea L. ssp. minus (Lodd.) Hulten

Valeriana capitata Pallas ex Link

* Veronica peregrina L. ssp. xalapensis (Kunth) Pennell

* Veronica wormskjoldii Roemer \& J.A. Schultes

Viburnum edule (Michx.) Raf.

Viola biflora L.

Viola epipsila Ledeb.

*Viola selkirkii Pursh ex Goldie

Wilhelmsia physodes (Fisch.) McNeill

* Woodsia glabella R. Br. ex Richards.

Woodsia ilvensis (L.) R. Br.

Zigadenus elegans Pursh 


\section{APPENDIX B: CHECKLIST OF COLLECTED VASCULAR PLANTS FROM FORT GREELY MILITARY INSTALLATION, ALASKA, ARRANGED BY FAMILY}

Nomenclature of this checklist follows the University of Alaska Museum Plants Database (ALABASE). Recent revisions have resulted in some name changes; if the plant name is different from that used in Hulten (1968), its synonym is presented in brackets.

\section{Adiantaceae [including Cryptogrammaceae]}

Cryptogramma stelleri (Gmel.) Prantl

\section{Adoxaceae}

Adoxa moschatellina $\mathrm{L}$.

Apiaceae [=Umbelliferae]

Angelica lucida L.

Bupleurum triradiatum Adams ssp. arcticum (Regel) Hulten

Cnidium cnidiifolium (Turcz.) Schischk.

Podistera macounii (Coult. \& Rose) Mathias \& Constance [= Ligusticum mutellinioides

(Crantz) Willar ssp. alpinum (Ledeb.) Thell.]

\section{Aspleniaceae [including Athyriaceae, Aspidiaceae]}

Cystopteris fragilis (L.) Bernh.

Cystopteris fragilis (L.) Bernh. ssp. dickieana (Sim) Hyl.

Cystopteris montana (Lam.) Bernh. ex Desv.

Dryopteris fragrans (L.) Schott

Gymnocarpium dryopteris (L.) Newman

Woodsia glabella R. Br. ex Richards.

Woodsia ilvensis (L.) R. Br.

\section{Asteraceae [ $=$ Compositae]}

Achillea borealis Bong.

Achillea millefolium L. sensu Hulten

Achillea sibirica Ledeb.

Antennaria friesiana (Trautv.) Ekman

Antennaria monocephala DC. ssp. monocephala

Antennaria monocephala DC. ssp. philonipha (A. Porsild) Hulten

Arnica angustifolia M. Vahl [= Arnica alpina (L.) Olin ssp. angustifolia (M. Vahl)

Maguire]

Arnica griscomii Fern. ssp. frigida (C.A. Mey. ex Iljin) S. J. Wolf [= Arnica frigida C.A.

Mey. ex Iljin]

Arnica lessingii (Torr. \& Gray) Greene

Artemisia alaskana Rydb.

Artemisia arctica Less.

Artemisia borealis Pallas

Artemisia frigida Willd.

Artemisia globularia Cham. ex Bess.

Artemisia laciniata Willd.

Artemisia tilesii Ledeb. ssp. elatior (Torr. \& Gray) Hulten

Aster sibiricus L.

Crepis elegans Hook.

Crepis nana Richards.

Erigeron acris L.

Erigeron caespitosus Nutt. 
Erigeron elatus E. Greene

Erigeron eriocephalus J. Vahl

Erigeron glabellus Nutt. ssp. pubescens (Hook.) Cronq.

Erigeron humilis Graham

Erigeron lonchophyllus Hook.

Erigeron purpuratus Greene

Gnaphalium uliginosum L.

Matricaria matricarioides (Less.) Porter

Petasites frigidus (L.) Fries

Petasites sagittatus (Banks ex Pursh) Gray

Saussurea angustifolia (Willd.) DC. (including one specimen that fits Saussurea viscida

Hulten var. yukonensis (Pors.) sensu Hulten)

Senecio atropurpureus (Ledeb.) Fedtsch.

Senecio congestus (R. Br.) DC.

Senecio kjellmannii [= Senecio atropurpureus (Ledeb.) Fedtsch. ssp. tomentosus

(Kjellm.) Hulten]

Senecio lugens Richards.

Senecio ogotorukensis Packer [= Senecio conterminus Greenm.]

Senecio pauciflorus Pursh

Senecio pauperculus Michx.

Senecio resedifolius Less.

Senecio tundricola Tolm. [= Senecio fuscatus (Jord. \& Fourr.) Hayek]

Senecio yukonensis Porsild

Solidago decumbens Greene var. oreophila (Rydb.) Fern.

Solidago multiradiata Ait.

Taraxacum kamtschaticum Dahlst.

Taraxacum lacerum E. Greene

Betulaceae

Alnus sinuata (Regel) Rydb. [= Alnus crispa (Ait.) Pursh ssp. sinuata (Regel) Hulten]

Alnus tenuifolia Nutt. [= Alnus incana (L.) Moench ssp. tenuifolia (Nutt.) Breitung]

Alnus viridis Vill. ssp. crispa (Ait.) A. Love \& D. Love [= Alnus crispa (Ait.) Pursh ssp. crispa]

Betula glandulosa Michx.

Betula hybrid

Betula nana L.

Betula neoalaskana Sarg. [= Betula papyrifera Marsh. ssp. humilis (Regel) Hulten]

Betula papyrifera Marsh.

Boraginaceae

Eritrichium splendens Kearney

Mertensia paniculata (Ait.) G. Don

Myosotis alpestris F. W. Schmidt ssp. asiatica Vestergr.

Brassicaceae [ $=$ Cruciferae $]$

Arabis hirsuta (L.) Scop. ssp. pycnocarpa (M. Hopk.) Hulten

Arabis lyrata L. ssp. kamchatica (Fisch.) Hulten

Barbarea orthoceras Ledeb.

Cardamine bellidifolia $\mathrm{L}$.

Cardamine purpurea Cham. \& Schlecht.

Cardamine umbellata E. Greene

Descurainia richardsonii (Sweet) O. Schulz

Descurainia sophioides (Fisch. ex Hook.) O.E. Schulz

Draba alpina L. complex 
Draba cana Rydb. [= Draba lanceolata Royle]

Draba glabella Pursh var. glabella Pursh [= Draba hirta L.]

Draba incerta Payson

Draba lonchocarpa Rydb. var. lonchocarpa

Draba longipes Raup

Draba nivalis Lilj.

Draba stenopetala Trautv.

Erysimum cheiranthoides L.

Eutrema edwardsii R. Br.

Lepidium densiflorum Schrad.

Lesquerella arctica (Wormsk. ex Hornem.) S. Wats.

Parrya nudicaulis (L.) Boiss.

Rorippa barbareifolia (DC.) Kitigawa [= Rorippa hispida (Desv.) Britt. var. barbareaefolia (DC.) Hulten]

Rorippa palustris (L.) Besser ssp. glabra (O. Schulz) Stuckey [= Rorippa islandica (Oeder) Borb. ssp. fernaldiana (Butt. \& Abbe) Hulten]

Subularia aquatica $\mathrm{L}$.

Torularia humilis (C. Meyer) O. Schulz [= Braya humilis (C.A. Mey.) B.L. Robins.]

\section{Callitrichaceae}

Callitriche hermaphroditica $\mathrm{L}$.

Callitriche verna $\mathrm{L}$. emend. Kutz.

\section{Campanulaceae}

Campanula lasiocarpa Cham. ssp. lasiocarpa

Campanula uniflora $\mathrm{L}$.

\section{Caprifoliaceae}

Linnaea borealis L. ssp. americanus (J. Forbes) Hulten

Linnaea borealis L. ssp. borealis L.

Viburnum edule (Michx.) Raf.

\section{Caryophyllaceae}

Arenaria capillaris Poir.

Cerastium beeringianum Cham. \& Schlecht.

Cerastium beeringianum Cham. \& Schlecht. var. beeringianum

Cerastium fontanum Baumg.

Gastrolychnis affinis (J. Vahl) Tolm. \& Koznanch. [= Melandrium affine J. Vahl]

Gastrolychnis apetala (L.) Tolm. \& Kozhanch. [= Melandrium apetalum (L.) Fenzl ssp. arcticum (E. Fries) Hulten]

Gastrolychnis ostenfeldii (A. Pors.) D. Murray [= Melandrium taimyrense Tolm.]

Minuartia arctica (Stev. ex Ser.) Graebn.

Minuartia dawsonensis (Britt.) House

Minuartia macrocarpa (Pursh) Ostenf.

Minuartia obtusiloba (Rydb.) House

Minuartia rossii (R. Br.) Graebn.

Minuartia rubella (Wahlenb.) Hiern

Moehringia lateriflora (L.) Fenzl

Sagina nivalis (Lindbl.) Fries [= Sagina intermedia Fenzl]

Silene acaulis (L.) Jacq.

Silene repens Patrin ex Pers.

Silene williamsii Britt. [= Silene menziesii Hook. ssp. williamsii (Britt.) Hulten]

Stellaria alaskana Hulten

Stellaria borealis Bigelow 
Stellaria calycantha (Ledeb.) Bong.

Stellaria crassifolia Ehrh.

Stellaria edwardsii R. Br.

Stellaria laeta Richardson

Stellaria longifolia Muhl. ex Willd.

Stellaria longipes Goldie

Wilhelmsia physodes (Fisch.) McNeill

Chenopodiaceae

Chenopodium album $\mathrm{L}$.

Chenopodium capitatum (L.) Aschers.

\section{Cornaceae}

Cornus canadensis L.

Crassulaceae

Rhodiola integrifolia Raf. [= Sedum rosea (L.) Scop. ssp. integrifolium (Raf.) Hulten]

\section{Cupressaceae}

Juniperus communis L. ssp. nana (Willd.) Syme

\section{Cyperaceae}

Carex aenea Fern.

Carex aquatilis Wahlenb.

Carex aquatilis Wahlenb. ssp. aquatilis

Carex arcta Boott

Carex atherodes Spreng.

Carex atratiformis Britt. ssp. raymondii (Calder) Pors. [= Carex raymondii Calder]

Carex aurea Nutt.

Carex bicolor Bellardi ex All.

Carex bigelowii Torr. ex Schwein.

Carex canescens $\mathrm{L}$.

Carex capillaris $\mathrm{L}$.

Carex capitata $\mathrm{L}$.

Carex concinna $\mathrm{R}$. Br.

Carex crawfordii Fern.

Carex cf. deweyana Schwein.

Carex diandra Schrank

Carex disperma Dew.

Carex eburnea Boott

Carex filifolia Nutt.

Carex garberi Fern. ssp. bifaria (Fern.) Hulten

Carex gynocrates Wormsk. ex Drej. [= Carex dioica L. ssp. gynocrates (Wormsk.) Hulten]

Carex kelloggii W. Boott

Carex krausei Boeckl.

Carex lachenalii Schkuhr.

Carex limosa L.

Carex livida (Wahlenb.) Willd.

Carex lugens Holm

Carex macloviana d'Urv. [= Carex macloviana d'Urv. ssp. pachystachya (Cham.)

Hulten]

Carex magellanica Lam. ssp. irrigua (Wahlenb.) Hulten

Carex media R. Br. 
Carex membranacea Hook.

Carex microchaeta Holm

Carex microchaeta Holm ssp. microchaeta

Carex microchaeta Holm ssp. nesophila (Holm) D. Murray

Carex microglochin Wahlenb.

Carex oederi Retz. ssp. viridula (Michx.) Hulten

Carex petricosa Dewey

Carex podocarpa $\mathrm{R}$. Br.

Carex rostrata Stokes

Carex rotundata Wahlenb.

Carex cf. rotundata Wahlenb.

Carex rupestris All.

Carex saxatilis L. ssp. laxa (Trautv.) Kalela

Carex scirpoidea Michx.

Carex supina Willd. ex Wahlenb. var. spaniocarpa (Steud.) Boivin

Carex sychnocephala Carey

Carex tenuiflora Wahlenb.

Carex utriculata Boott [= Carex rhynchophysa C. A. Meyer]

Carex vaginata Tausch

Carex williamsii Britt.

Eleocharis acicularis (L.) Roem. \& Schult

Eleocharis palustris (L.) Roem. \& Schult.

Eriophorum angustifolium Honck. ssp. subarcticum (Vassiljev) Hulten

Eriophorum brachyantherum Trautv. \& C.A. Mey.

Eriophorum gracile W.D.J. Koch

Eriophorum russeolum Fries

Eriophorum scheuchzeri Hoppe

Eriophorum scheuchzeri Hoppe var. tenuifolium Ohwi

Eriophorum vaginatum L.

Kobresia myosuroides (Vill.) Fiori

Scirpus validus M. Vahl

Trichophorum caespitosum (L.) Hartman

Diapensiaceae

Diapensia lapponica L. ssp. obovata (F.Schm.) Hulten

\section{Droseraceae}

Drosera rotundifolia $\mathrm{L}$.

\section{Elaeagnaceae}

Elaeagnus commutata Bernh. ex Rydb.

Shepherdia canadensis (L.) Nutt.

\section{Empetraceae}

Empetrum hermaphroditum Lange ex Hagerup [= Empetrum nigrum L. ssp. hermaphroditum (Lange ex Hagerup) Bocher]

\section{Equisetaceae}

Equisetum arvense L.

Equisetum fluviatile L. ampl Ehrh.

Equisetum palustre L.

Equisetum pratense Ehrh.

Equisetum scirpoides Michx.

Equisetum silvaticum L.

Equisetum variegatum Schleich. ex F. Weber \& D.M.H. Mohr 


\section{Ericaceae}

Andromeda polifolia $\mathrm{L}$.

Arctostaphylos uva-ursi (L.) Spreng. var uva-ursi

Arctous alpina (L.) Niedenzu [= Arctostaphylos alpina (L.) Spreng.]

Arctous rubra [= Arctostaphylos rubra (Rehd. \& Wilson) Fern.]

Cassiope tetragona (L.) D. Don ssp. tetragona

Chamaedaphne calyculata (L.) Moench

Ledum groenlandicum Oeder [= Ledum palustre L. ssp. groenlandicum (Oeder) Hulten]

Ledum palustre L. ssp. decumbens (Ait.) Hulten

Loiseleuria procumbens (L.) Desv.

Oxycoccus microcarpus Turcz.

Rhododendron lapponicum (L.) Wahlenb.

Vaccinium uliginosum $\mathrm{L}$.

Vaccinium vitis-idaea L. ssp. minus (Lodd.) Hulten

Fabaceae [= Leguminosae]

Astragalus adsurgens Pallas ssp. viciifolius (Hulten) Welsh

Astragalus alpinus L.

Astragalus americanus (Hook.) M.E. Jones

Astragalus bodinii Sheldon

Astragalus eucosmus Robins. ssp. eucosmus

Astragalus umbellatus Bunge

Astragalus williamsii Rydb.

Hedysarum alpinum $\mathrm{L}$.

Hedysarum hedysaroides (L.) Schinz \& Thell.

Hedysarum mackenzii Richards.

Lupinus arcticus $\mathrm{S}$. Wats.

Oxytropis bryophila (E. Greene) Yurtsev [= Oxytropis nigrescens (Pallas) Fisch. ex DC. ssp. bryophila]

Oxytropis deflexa (Pallas) DC. var. foliolosa (Hook.) Barneby

Oxytropis deflexa (Pallas) DC. var. sericea Torr. \& Gray

Oxytropis maydelliana Trautv.

Oxytropis varians (Rydb.) Schumann [= Oxytropis campestris (L.) DC. ssp. gracilis

(Nels.) Hulten]

Oxytropis viscida Nutt.

Trifolium hybridum L.

\section{Fumariaceae}

Corydalis sempervirens (L.) Pers.

\section{Gentianaceae}

Gentiana algida Pall.

Gentiana glauca Pallas

Gentiana prostrata Haenke

Gentianella propinqua (Richards.) J. Gillett ssp. propinqua (Richards.) J. Gillett [= Gentiana propinqua Richards. ssp. propinqua]

Gentianopsis detonsa (Rottb.) Ma ssp. yukonensis (J. Gillett) J. Gillett [= Gentiana barbata Froel.]

Lomatogonium rotatum (L.) Fries ex Fern.

\section{Grossulariaceae [= Saxifragaceae, in part]}

Ribes hudsonianum Richards.

Ribes triste Pallas 


\section{Haloragaceae}

Hippuris vulgaris L.

Myriophyllum sibiricum Kom. [= Myriophyllum spicatum L.]

\section{Iridaceae}

Iris setosa Pallas ex Link var. interior E. Anders.

Sisyrinchium montanum Greene

\section{Isoetaceae}

Isoetes echinospora Durieu [= Isoetes muricata Dur. var braunii auct.]

\section{Juncaceae}

Juncus alpinus Vill.

Juncus arcticus Willd. ssp. alaskanus Hulten

Juncus arcticus Willd. ssp. ater (Rydb.) Hulten

Juncus biglumis L.

Juncus bufonius L.

Juncus castaneus Sm. ssp. castaneus

Juncus castaneus Sm. ssp. leucochlamys (Zing. ex Krecz.) Hulten

Juncus filiformis L.

Juncus triglumis L. ssp. albescens (Lange) Hulten

Luzula arcuata (Wahlenb.) Sw. ssp. arcuata (Wahlenb.) Sw.

Luzula confusa Lindeberg

Luzula multiflora (Retz.) Lej. ssp. multiflora var. frigida (Buch.) Sam.

Luzula parviflora (Ehrh.) Desv.

Luzula rufescens Fisch. ex E. Mey.

Luzula spicata (L.) DC.

Luzula tundricola Gorodk.

Juncaginaceae

Triglochin palustre L.

\section{Lamiaceae}

Dracocephalum parviflorum Nutt.

\section{Lentibulariaceae}

Pinguicula villosa L.

Pinguicula vulgaris L.

Utricularia intermedia Hayne

Utricularia minor $\mathrm{L}$.

Utricularia vulgaris L. ssp. macrorhiza (Le Conte) R.T. Clausen

\section{Liliaceae}

Allium schoenoprasum L.

Lloydia serotina (L.) Reichenb.

Tofieldia coccinea Richards.

Tofieldia pusilla (Michx.) Pers.

Zigadenus elegans Pursh

\section{Linaceae}

Linum lewisii Pursh [=Linum perenne L. ssp. lewisii (Pursh) Hulten]

\section{Lycopodiaceae}

Diphasiastrum alpinum (L.) Holub [= Lycopodium alpinum L.] 
Diphasiastrum complanatum (L.) Holub [= Lycopodium complanatum L.]

Huperzia selago (L.) Bernh. ex Mart. \& Schrank [= Lycopodium selago L. ssp.

appressum (Desv.) Hulten, Huperzia haleakalensis (Breck.) Holub in FNA (1993)]

Lycopodium annotinum $\mathrm{L}$. ssp. annotinum

Lycopodium annotinum L. ssp. pungens (LA Pyl.) Hult

Lycopodium clavatum L. var. monostachyon Grev. \& Hook.

Myricaceae

Myrica gale L.

Nymphaceae

Nuphar polysepalum Engelm.

Onagraceae

Epilobium angustifolium $\mathrm{L}$.

Epilobium ciliatum Raf. ssp. adenocaulon (Haussk.) Hoch \& Raven [= Epilobium adenocaulon Haussk.]

Epilobium hornemannii Rchb. ssp. hornemannii

Epilobium latifolium $\mathrm{L}$.

Epilobium palustre L.

Ophioglossaceae

Botrychium lunaria (L.) Sw.

\section{Orchidaceae}

Calypso bulbosa (L.) Oakes

Corallorrhiza trifida Chatelain

Cypripedium guttatum Sw.

Cypripedium passerinum Richards.

Goodyera repens (L.) R. Br. ex Ait. f.

Platanthera hyperborea (L.) Lindl.

Platanthera obtusata (Banks ex Pursh) Lindl.

Spiranthes romanzoffiana Cham.

\section{Orobanchaceae}

Boschniakia rossica (Cham. \& Schlecht.) Fedtsch.

\section{Papaveraceae}

Papaver macounii Greene

Papaver radicatum Rottb. ssp. radicatum [= Papaver lapponicum (Tolm.) Nordh. ssp. occidentale (Lundstr.) Knaben]

\section{Pinaceae}

Larix laricina (Du Roi) K. Koch

Picea glauca (Moench) Voss

Picea mariana (P. Mill.) B.S.P.

\section{Plantaginaceae}

Plantago canescens M.F. Adams

Plantago major L.

Poaceae [=Graminae]

Agrostis scabra Willd. 
Alopecurus aequalis Sobol.

Arctagrostis latifolia (R. Br.) Griseb. ssp. arundinacea (Trin.) Tzvelev

Arctagrostis latifolia (R. Br.) Griseb. ssp. latifolia (R. Br.) Griseb.

Arctophila fulva (Trin.) Rupr. ex Anderss.

Avena sativa $\mathrm{L}$.

Beckmannia erucaeformis (L.) Host ssp. baicalensis (Kuzn.) Hulten

Bromopsis inermis (Leyss.) Holub [= Bromus inermis Leyss.]

Bromopsis pumpelliana (Scribn.) Holub ssp. pumpellianus [= Bromus pumpellianus

Scribn. var. pumpellianus]

Calamagrostis canadensis (Michx.) Beauv.

Calamagrostis canadensis (Michx.) Beauv. ssp. canadensis

Calamagrostis inexpansa Gray

Calamagrostis purpurascens $\mathrm{R}$. Br.

Deschampsia cespitosa (L.) Beauv.

Elymus alaskanus (Scribn. \& Merr.) A. Love ssp. hyperarcticus (Polunin) A. Love \& D.

Love [= Agropyron boreale (Turcz.) Drobov ssp. hyparcticum (Polunin) Melderis]

Elymus cf. macrourus (Turcz.) Tzvelev [= Agropyron macrourum (Turcz.) Drobov]

Elymus trachycaulus (Link) Gould ex Shinners cf. ssp. subsecundus (Link) Gould [= Agropyron subsecundum (Link) Hitchc.]

Elymus trachycaulus (Link) Gould ex Shinners ssp. trachycaulus [= Agropyron

pauciflorum (Schwein.) Hitchc.]

Elymus trachycaulus (Link) Gould ex Shinners ssp. violaceus (Hornem.) A. \& D. Love [= Agropyron violaceum (Hornem.) Lange]

Elytrigia repens (L.) Beauv. var. repens [= Agropyron repens (L.) Beauv.]

Festuca altaica Trin.

Festuca brachyphylla J.A. Schultes ex J.A. \& J.H. Schultes

Festuca brevissima Yurtsev [=Festuca ovina L. ssp. alaskensis Holmen]

Festuca rubra L. sens lat.

Festuca rubra L. ssp. richardsonii (R. Br.) Hulten [= Festuca rubra L., in part]

Festuca saximontana $\mathrm{Rydb}$.

Festuca vivipara $($ L.) Smith [= "Festuca vivipara"]

Glyceria borealis (Nash) Batchelder

Glyceria maxima (Hartm.) Holmb. ssp. grandis (S. Wats.) Hulten

Glyceria pulchella (Nash) K. Schum.

Hierochloe alpina (Sw.) Roem. \& Schult.

Hierochloe odorata (L.) Beauv.

Hordeum jubatum $\mathrm{L}$.

Leymus innovatus (Beal) Pilger [= Elymus innovatus Beal]

Phleum pratense $\mathrm{L}$.

Poa cf. alpigena (Fries) Lindman

Poa alpina L.

Poа аппиа L.

Poa arctica $\mathrm{R}$. Br. sens lat.

Poa glauca M. Vahl

Poa lanata Scribn. \& Merr.

Poa paucispicula Scribn. \& Merr.

Poa pratensis L.

Poa pseudoabbreviata Rosh.

Poa secunda J. Presl [= includes Poa nevadensis Vasey, Poa ampla Merrill, Poa

stenantha, in part, Poa scabrella (Thurb.) Benth. and Poa canbyi (Scribn.) Howell]

Trisetum spicatum (L.) Richter 


\section{Polemoniaceae}

Phlox hoodii Richards.

Phlox sibirica L. ssp. richardsonii (Hook.) Hulten

Polemonium acutiflorum Willd. ex Roemer \& J.A. Schultes

Polemonium pulcherrimum Hook.

\section{Polygonaceae}

Bistorta plumosa (Small) E. Greene [= Polygonum bistorta L. ssp. plumosum (Small) Hulten]

Bistorta vivipara (L.) Gray [= Polygonum viviparum L.]

Oxyria digyna (L.) Hill

Polygonum alaskanum (Small) W. Wight

Polygonum amphibium L.

Polygonum aviculare L.

Polygonum pennsylvanicum L. ssp. oneillii (Brenckle) Hulten

Rumex arcticus Trautv.

Rumex longifolius DC.

Rumex maritimus L. ssp. fueginus (L. Phillips) Hulten

Rumex maritimus L. ssp. maritimus

\section{Portulacaceae}

Claytonia sarmentosa C.A. Mey.

Claytonia tuberosa Pallas ex J.A. Schultes

\section{Potamogetonaceae}

Potamogeton alpinus Balbis

Potamogeton filiformis Pers.

Potamogeton foliosus Raf.

Potamogeton gramineus L.

Potamogeton obtusifolius Mertens \& Koch

Potamogeton praelongus Wulfen

Potamogeton pusillus L. [= Potamogeton berchtoldii Fieb.]

Potamogeton richardsonii (Benn.) Rydb. [= Potamogeton perfoliatus L. ssp. richardsonii (Bennett) Hulten]

Potamogeton zosteriformis Fern. [= Potamogeton zosterifolius Schum. ssp. zosteriformis (Fern.) Hulten]

\section{Primulaceae}

Androsace chamaejasme Wulfen ssp. lehmanniana (Spreng.) Hulten

Androsace septentrionalis L.

Dodecatheon frigidum Cham. \& Schlecht.

Dodecatheon pulchellum (Raf.) Merr. ssp. pauciflorum (E. Greene) Hulten Primula cf. egaliksensis Wormsk. ex Hornem.

Primula eximia Greene [= Primula tschuktschorum Kjellm. var. arctica (Koidz.) Fern.]

Trientalis europaea L. ssp. arctica (Fisch. ex Hook.) Hulten

\section{Pyrolaceae}

Moneses uniflora (L.) Gray

Orthilia secunda (L.) House [= Pyrola secunda L.]

Pyrola asarifolia Michx.

Pyrola chlorantha Sw.

Pyrola grandiflora Radius

Pyrola minor L. 


\section{Ranunculaceae}

Aconitum delphinifolium DC. ssp. delphinifolium

Actaea rubra (Ait.) Willd.

Anemone drummondii S. Wats.

Anemone narcissiflora L. ssp. interior Hulten

Anemone parviflora Michx.

Anemone richardsonii Hook.

Aquilegia brevistyla Hook.

Delphinium glaucum S. Wats.

Pulsatilla patens (L.) P. Mill. ssp. multifida (Pritz.) Zamels

Ranunculus gmelini DC. ssp. gmelini

Ranunculus hyperboreus Rottb.

Ranunculus lapponicus $\mathrm{L}$.

Ranunculus nivalis $\mathrm{L}$.

Ranunculus reptans $\mathrm{L}$.

Ranunculus sceleratus L. ssp. multifidus (Nutt.) Hulten

Ranunculus trichophyllus Chaix

Thalictrum alpinum L.

Thalictrum sparsiflorum Turcz. ex Fisch. \& C.A. Mey.

\section{Rosaceae}

Acomastylis rossii (R. Br.) E. Greene [= Geum rossii (R. Br.) Ser.]

Comarum palustre L. [= Potentilla palustris (L.) Scop.]

Dryas alaskensis A. Porsild [= Dryas octopetala L. ssp. alaskensis (Porsild) Hulten]

Dryas drummondii Richards. ex Hook.

Dryas integrifolia Vahl

Dryas octopetala L.

Dryas octopetala L. ssp. octopetala var. octopetala

Fragaria virginiana Duchesne ssp. glauca (S. Wats.) Staudt

Geum perincisum Rydb. [= Geum macrophyllum Willd. var. perincisum (Rydb.) Raup]

Pentaphylloides floribunda (Pursh) A. Love [= Potentilla fruticosa L.]

Potentilla anserina $\mathrm{L}$.

Potentilla biflora Willd. ex Schlecht.

Potentilla hookeriana Lehm.

Potentilla multifida L.

Potentilla norvegica L. ssp. monspeliensis (L.) Ashers. \& Graebn.

Potentilla pensylvanica L.

Potentilla uniflora Ledeb.

Potentilla virgulata A. Nels.

Rosa acicularis Lindl.

Rubus arcticus L. ssp. arcticus L.

Rubus chamaemorus L.

Rubus idaeus L.

Sanguisorba officinalis L.

Sanguisorba stipulata Raf.

Spiraea stevenii (Schneid.) Rydb. [= Spiraea beauverdiana Schneid.]

\section{Rubiaceae}

Galium boreale L.

Galium brandegei A. Gray

Galium trifidum L. ssp. trifidum

Salicaceae

Populus balsamifera L. ssp. balsamifera 
Populus tremuloides Michx.

Salix alaxensis (Anderss.) Coville var. alaxensis (Anderss.) Coville

Salix alaxensis (Anderss.) Coville var. longistylis (Rydb.) Schneid.

Salix arbusculoides Anderss.

Salix arctica Pall.

Salix barclayi Anderss.

Salix bebbiana Sarg. [= Salix depressa L. ssp. rostrata (Anderss.) Hiitonen]

Salix brachycarpa Nutt. ssp. niphoclada (Rydb.) Argus

Salix fuscescens Anderss.

Salix glauca $\mathrm{L}$.

Salix glauca L. var. acutifolia (Andersson) C. Schneider

Salix lanata L. ssp. richardsonii (Hook.) A. Skvortsov

Salix myrtillifolia Anderss.

Salix novae-angliae Anderss. [= Salix myrtillifolia Anderss., in part]

Salix planifolia Pursh ssp. pulchra (Cham.) Argus

Salix polaris Wahlenb. ssp. pseudopolaris (Flod.) Hulten

Salix reticulata L.

Salix rotundifolia Trautv. ssp. dodgeana (Rydb.) Argus [= Salix dodgeana Rydb.]

Salix setchelliana Ball

Santalaceae

Geocaulon lividum (Richards.) Fern.

\section{Saxifragaceae}

Boykinia richardsonii (Hook.) Rothrock

Chrysosplenium tetrandrum (Lund) Th. Fries

Chrysosplenium wrightii Franch. \& Savigny

Parnassia kotzebuei Cham. ex Spreng.

Parnassia palustris L. ssp. neogaea (Fern.) Hulten

Saxifraga cf. adscendens L. ssp. oregonensis (Raf.) Bacig.

Saxifraga bronchialis L.

Saxifraga calycina Sternb. [= Saxifraga davurica Willd. ssp. grandipetala (Engler \& Irmsch) Hulten]

Saxifraga cernua L.

Saxifraga eschscholtzii Sternb.

Saxifraga flagellaris Willd. ex Sternb.

Saxifraga hieraciifolia Waldst. \& Kit

Saxifraga hirculus L.

Saxifraga nelsoniana D. Don [= Saxifraga punctata L.]

Saxifraga oppositifolia L.

Saxifraga reflexa Hook.

Saxifraga rivularis L.

Saxifraga serpyllifolia Pursh

Saxifraga spicata D. Don

Saxifraga tricuspidata Rottb.

\section{Scrophulariaceae}

Castilleja caudata (Pennell) Rebr.

Castilleja yukonis Pennell

Euphrasia disjuncta Fern. \& Wieg.

Lagotis glauca Gaertn.

Pedicularis capitata M.F. Adams

Pedicularis labradorica Wirsing

Pedicularis lanata Cham. \& Schlecht. [= Pedicularis kanei Durand] 
Pedicularis langsdorfii Fisch. ex Stev.

Pedicularis sudetica Willd.

Pedicularis verticillata $\mathrm{L}$.

Rhinanthus minor L. ssp. borealis (Sterneck) Love

Synthyris borealis Pennell

Veronica peregrina L. ssp. xalapensis (Kunth) Pennell

Veronica wormskjoldii Roemer \& J.A. Schultes

Selaginellaceae

Selaginella sibirica (Milde) Hieron.

\section{Sparganiaceae}

Sparganium angustifolium Michx.

Sparganium hyperboreum Laestad. ex Beurling

Sparganium minimum (Hartman F.) Fries

\section{Valerianaceae}

Valeriana capitata Pallas ex Link

\section{Violaceae}

Viola biflora L.

Viola epipsila Ledeb.

Viola selkirkii Pursh ex Goldie 


\section{APPENDIX C: COLLECTIONS AT ALA FOR BIG DELTA AND MT. HAYES AREA QUADRANGLES (ALA 1997) BUT NOT FOUND ON THE PRESENT INVENTORY OF FORT GREELY}

Antennaria pulcherrima (Hook.) Greene

Antennaria rosea Greene ssp. arida (E. Nels.) Bayer

Artemisia laciniatiformis Kom.

Aster alpinus L.

Aster junciformis Rydb.

Astragalus robbinsii (Oakes) Gray

Braya bartlettiana Jordal

Calla palustris $\mathrm{L}$.

Caltha palustris $\mathrm{L}$.

Cardamine pratensis $\mathrm{L}$.

Carex buxbaumii Wahlenb.

Carex lasiocarpa Ehrh.

Carex maritima Gunn.

Carex obtusata Lilj.

Carex rossii Boott

Castilleja elegans Malte

Cerastium maximum $\mathrm{L}$.

Cicuta virosa L. [= C. mackenzieana Raup $]$

Cornus suecica $\mathrm{L}$.

Elymus alaskanus (Scribn. \& Merr.) A. Love ssp. latiglumis (Scribn. \& J.G. Sm.) A. Love [= Agropyron violaceum (Hornem.) Lange ssp. violaceum]

Elytrigia spicata (Pursh) D. R. Dewey [= Agropyron spicatum (Pursh.) Scribn. \& Smith]

Equisetum hiemale L.

Erigeron alpinus Hook. [=E. acris L., in part?]

Galium triflorum Michx.

Kobresia simpliciuscula (Wahlenb.) Mackenzie

Koeleria gracilis Pers.

Lemna minor L.

Lemna trisulca $\mathrm{L}$.

Listera borealis Morong

Luzula kjellmaniana Miyabe \& Kudo

Menyanthes trifoliata L.

Mimulus guttatus DC.

Oxytropis gorodkovii Yurtsev [= Oxytropus nigrescens (Pall.) Fisch. group]

Oxytropis splendens Dougl. ex Hook.

Oxytropis tananensis Yurtsev [= Oxytropis campestris (L.) DC. ssp. gracilis (Nels.)

Hulten, in part]

Papaver lapponicum (Tolm.) Nordh.

Papaver nudicaule $\mathrm{L}$

Papaver nudicaule L. ssp. americanum Randel ex Murray

Pedicularis oederi Vahl ex Hornem.

Penstemon gormanii Greene

Phacelia mollis J.F. Macbr.

Polygonum convolvulus L.

Potamogeton vaginatus Turcz.

Potentilla furcata A. E. Porsild [= Potentilla hookeriana Lehm. ssp. hookeriana var.

furcata (Pors.) Hulten

Primula incana M.E. Jones

Ranunculus eschscholtzii Schlecht.

Sagittaria cuneata Sheldon 
Salix athabascensis Raup

Salix candida Fluegge ex Willd.

Salix interior Rowlee

Salix pseudomonticola C. Ball

Salix scouleriana Barratt ex Hook.

Senecio streptanthifolius E. Greene [= S. cymbalariodesNutt, sensu Hulten, in part]

Senecio streptanthifolius E. Greene var. kluanei Bain [= S. cymbalariodesNutt, sensu Hulten, in part]

Swida stolonifera (Michx.) Rydb. [= Cornus stolonifera Michx.]

Triglochin maritimum $\mathrm{L}$.

Urtica dioica $\mathrm{L}$.

Valeriana sitchensis Bong.

Woodsia alpina (Bolton) S.F. Gray 


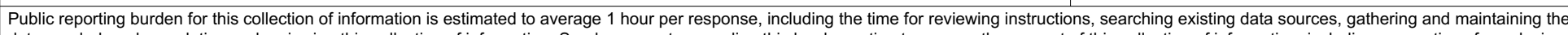

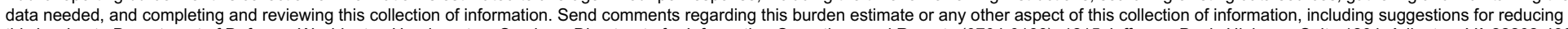

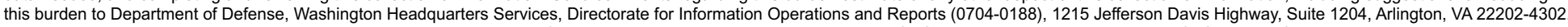

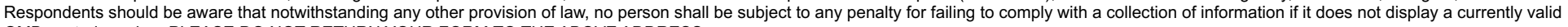
OMB control number. PLEASE DO NOT RETURN YOUR FORM TO THE ABOVE ADDRESS.
1. REPORT DATE (DD-MM-YY)
2. REPORT TYPE
3. DATES COVERED (From - To)

February 2001

Technical Report

4. TITLE AND SUBTITLE

5a. CONTRACT NUMBER

An Inventory of the Vascular Flora of Fort Greely, Interior Alaska

5b. GRANT NUMBER

5c. PROGRAM ELEMENT NUMBER

6. AUTHOR(S)

5d. PROJECT NUMBER

Charles Racine, Robert Lichvar, and Michael Duffy

5e. TASK NUMBER

5f. WORK UNIT NUMBER

7. PERFORMING ORGANIZATION NAME(S) AND ADDRESS(ES)

U.S. Army Engineer Research and Development Center

Cold Regions Research and Engineering Laboratory

72 Lyme Road

Hanover, New Hampshire 03755-1290

8. PERFORMING ORGANIZATION REPORT NUMBER

ERDC TR-01-5

9. SPONSORING/MONITORING AGENCY NAME(S) AND ADDRESS(ES)

10. SPONSOR / MONITOR'S ACRONYM(S)

USARAK

Fort Richardson, AK

11. SPONSOR / MONITOR'S REPORT NUMBER(S)

\section{DISTRIBUTION / AVAILABILITY STATEMENT}

Approved for public release; distribution is unlimited.

Available from NTIS, Springfield, Virginia 22161.

13. SUPPLEMENTARY NOTES

\section{ABSTRACT}

This inventory of the vascular flora of Fort Greely in interior Alaska was conducted sporadically during summer 1996, 1997 , and 1998. Fort Greely covers 0.66 million acres (267,763 ha) and is composed of five major subdivisions: 1) the large floodplains of Jarvis Creek, the Delta River, Delta Creek, and Little Delta River, 2) the surrounding lowlands associated with these rivers, 3) several glacial moraines, 4) two highland areas (Molybdemum Ridge and Dinosaur Ridge), and 5) the higher mountains of the Alaska Range (up to 2000 $\mathrm{m}$ in elevation) along the southern edge of the base. Habitats range from very dry south-facing slopes to forest, floodplains, wetlands, and alpine tundra. About 100 sites were visited and 723 collections made, which represented 497 taxa of vascular plants from 64 families and 198 genera. A species list for the Fort Greely survey was compiled and is presented here. It is estimated that the vascular plant inventory is relatively complete. The inventory includes 21 rare species being tracked by the Alaska Natural Heritage Program and 11 species representing significant range extensions $(>150 \mathrm{~km})$. The relationship of the Fort Greely flora to that inventoried on Fort Wainwright is discussed.

15. SUBJECT TERMS

Alaska Biodiversity
Interior Alaska

Vascular flora

\begin{tabular}{|c|c|c|c|c|c|}
\hline \multicolumn{3}{|c|}{ 16. SECURITY CLASSIFICATION OF: } & \multirow{2}{*}{$\begin{array}{l}\text { 17. LIMITATION OF } \\
\text { OF ABSTRACT }\end{array}$} & \multirow{2}{*}{$\begin{array}{l}\text { 18. NUMBER } \\
\text { OF PAGES }\end{array}$} & 19a. NAME OF RESPONSIBLE PERSON \\
\hline a. REPORT & b. ABSTRACT & c. THIS PAGE & & & 19b. TELEPHONE NUMBER (include area code) \\
\hline $\mathrm{U}$ & $\mathrm{U}$ & $\mathrm{U}$ & $\mathrm{U}$ & 52 & \\
\hline
\end{tabular}

